\title{
Educational Background and Stratification in the Legal Academy: \\ Invasion of the Body Snatchers... or More of the Same?
}

\author{
Heather A. Haveman ${ }^{*}$ \\ Ogi Radic ${ }^{* *}$
}

\author{
Introduction \\ I. Methodology \\ A. Population \\ B. Data Sources \\ C. Preparing the Data for Analysis \\ D. Measures: Law Professors \\ E. Measures: Educational Institutions \\ F. Methods of Analysis \\ II. Results \\ A. Law Professors' Educational Background \\ B. Relationships Between Law-Professor Educational Background and Law-School \\ Prestige \\ C. Relationships Among Law-Professor Gender, Educational Background, and Law- \\ School Prestige \\ III. Discussion
}
A. Law Professors
B. Law Schools

Conclusion

\footnotetext{
* Professor of Sociology and Business, the University of California, Berkeley. BA, University of Toronto, 1982; MBA, University of Toronto, 1985; PhD, University of California, Berkeley, 1990. We thank the Berkeley Population Center for financial support, Laura Nelson for transforming the raw DLT data into usable databases, Kristine Mo for helping us fill in missing data on law professors' educational histories, and Calvin Morrill and Jonathan Simon for perceptive comments.

** Doctoral student, the University of California, Berkeley. BA, Princeton University, 2004; JD, Columbia University, 2007.
} 


\section{Introduction}

Since the 1960s, law schools have seen an influx of faculty with graduate training and research presences in fields outside the law - primarily in the social sciences, statistics, and the humanities, but also in biology and medicine - which has brought "interdisciplinarity" into law schools, in the form of scholarship under the banners of "law and [ ]" or "critical [ ] studies." As their names suggest, these lines of inquiry either seek to extend traditional legal scholarship with complementary insights from external disciplines or else seek to question (if not overturn) traditional legal scholarship based on such insights. The rise of interdisciplinarity has been discussed in depth, with some scholars arguing that the rise of interdisciplinarity has strengthened the legal academy by broadening legal curricula and legal scholarship beyond traditional disciplinary law, while others aver that the rise of interdisciplinarity has reduced the autonomy of law in the university by introducing "alien" ideologies and practices. ${ }^{1}$

Despite this debate, there is little reliable or comprehensive evidence concerning where and when interdisciplinarity has entered the legal academy, specifically where and when scholars with training outside the legal academy have appeared. Most published studies are dated, providing little information about what has happened since the turn of the twenty-first century. ${ }^{2}$ Published studies with recent information focus mostly on the most prestigious law

\footnotetext{
${ }^{1}$ See e.g., Richard A. Posner, The Present Situation in Legal Scholarship, 90 Yale L.J. 1113 (1981); Richard A. Posner, The Decline of Law as an Autonomous Discipline: 1962-1987, 100 Harv. L. Rev. 761 (1987); Jane B. Baron, Interdisciplinary Scholarship as Guilty Pleasure: The Case of Law and Literature, in Law \& Literature 21 (Michael D.A. Freeman \& Andrew D.E. Lewis, eds. 1999); David E. Zandt, Discipline-Based Faculty, 53 J. Legal Educ. 332 (2003); Stephen M. Feldman, The Transformation of an Academic Discipline: Law Professors in the Past and Future (or Toy Story Too), 54 J. Legal Educ. 471 (2004); Jack M. Balkin \& Sanford Levinson, Law and the Humanities: An Uneasy Relationship, 18 Yale J.L. \& Human. 155 (2006); David A. Hollander, Interdisciplinary Legal Scholarship: What Can We Learn from Princeton's Long-Standing Tradition?, 99 L. Libr. J. 771 (2007); Tom Ginsburg \& Thomas J. Miles, Empiricism and the Rising Incidence of Coauthorship in Law, 2011 U. III. L. Rev. 1785, 1795 (2011); Olufunmilayo Arewa, Andrew P. Morriss \& William D. Henderson, Enduring Hierarchies in American Legal Education, 89 Ind. L.J. 941, 965 (2014).

${ }^{2}$ E.g., Robert J. Borthwick \& Jordan R. Schau, Note, Gatekeepers of the Profession: An Empirical Profile of the Nation's Law Professors, 25 U. Mich. J. L. Reform, 191, 194 n. 16 (1991) (in the 1988-89 academic year, 5\% of tenure-track faculty in all U.S. law schools had PhDs outside the law); Deborah Jones Merritt \& Barbara F. Reskin, Sex, Race, and Credentials: The Truth about Affirmative Action in Law Faculty Hiring, 97 Columbia L. Rev., 199 (1997) (in the 1990-91 academic year, 5\% of tenure-track faculty in all U.S. law schools had PhDs outside the law); Richard E. Redding, "Where Did You Go to Law School?" Gatekeeping for the Professoriate and Its Implications for Legal Education, 53 J. Legal Ed., 594 (2003) (between 1996 and 2000, 10\% of newly hired law professors had PhDs).
} 
schools ${ }^{3}$ or, if they cover all law schools, evaluate only new hires. ${ }^{4}$ The lack of recent information about the full range of faculty at the vast majority of law schools that are outside the top ranks limits the conclusions we can draw about the rise of interdisciplinarity in the American legal academy.

To fill this gap in our knowledge, we use data-science methods to gather and analyze "big data" on the educational backgrounds of all faculty who held tenured and tenure-track positions in all accredited law schools in the United States in the 2011-12 academic year. ${ }^{5}$ These data are richly detailed and comprehensive. They cover all law professors' full career histories, including all law schools where they worked, allowing us to chart temporal trends in interdisciplinarity. They also disclose law professors' gender, which allows us to compare the educational backgrounds of male and female law professors, to reveal a hitherto ignored relationship between interdisciplinarity and gender stratification in the legal academy.

Our analysis reveals a persistent increase in law-school faculty with PhDs, but most of those are faculty with both PhDs and JDs. This suggests that law schools have not been invaded

\footnotetext{
${ }^{3}$ E.g., Joni Hersch \& W. Kip Viscusi, Law and Economics as a Pillar of Legal Education, 8 Rev. of Law \& Econ., 487 (2012) (in the 2010-11 academic year, 27\% of tenured and tenure-track faculty in the 26 law schools ranked highest by the U.S. News \& World Report had PhDs outside the law); Lynn M. LoPucki, Dawn of the Discipline-Based Law Faculty, 65 J. Legal Ed., 506 (24\% of a random sample of 218 professors in 2009-2010 holding tenure-track positions at the 26 law schools ranked highest by the U.S. News \& World Report had PhDs); Justin McCrary, Joy Milligan, \& James Phillips, The PhD Rises in American Law Schools: What Does It Mean for Legal Education?, $65 \mathrm{~J}$. Legal Ed., 543 (in 2011, 28\% of tenure-track professors in the 34 law schools ranked highest by the U.S. News \& World Report had PhDs).

${ }^{4}$ LoPucki, supra $\mathrm{n} .3$ (based on reports to a legal academy blog (PrawfsBlawg), 21\% of tenure-track hires by all American law schools from 2011 to 2015 had PhDs).

${ }^{5}$ Data science is an interdisciplinary field that uses theories and automated techniques from mathematics, statistics, information science, computer science, and linguistics to gather, process, manage, analyze, and display richly detailed datasets, and communicate findings from analyzing them. These datasets are often quite large (1,000 gigabytes or more), so the term "big data" is commonly used to describe them, although there is no clear boundary between "big" and "small" data. Data-science methods are making inroads into the social sciences (e.g., Kevin Lewis, Jason Kaufman, Marco Gonzales, Andreas Wimmer, \& Nicholas Christakis, Tastes, Ties, and Times: A New Social Network Dataset using Facebook.com, 30 Soc. Networks, 330 (2008)) and the humanities (e.g., Franco Moretti \& Dominique Pestre, Bankspeak: The Language of World Bank Reports, 92 New Left Rev., 75 (2015)), as well as interdisciplinary legal scholarship (e.g., Lee Epstein, Andrew D. Martin, Kevin M. Quinn, \& Jeffrey A. Segal, Ideological Drift among Supreme Court Justices: Who, When, and How Important?, 101 Northwestern U. Law Rev., $1483(2007))$.
} 
by PhD-toting "pod people" importing alien values and practices from the arts and sciences. ${ }^{6}$

Rather than reducing the autonomy of the law, the influx of PhD-trained faculty is more likely to be promoting an intellectual culture and academic practices that are a hybrid of the traditional legal academy and the arts and sciences, which involves taking only selected external elements and adapting them to fit traditional law-school culture and practices, rather than adopting them wholesale to replace traditional law-school culture and practices. Such hybridization would yield more of (almost) the same culture and practices. Our analysis also reveals that although PhD-trained faculty are concentrated in the most prestigious law schools, the influx of PhD-trained faculty has trickled down the ranks to many less prestigious schools. This suggests that PhD credentials have become an important axis of competition in the law school market, in which prospective law professors increasingly accumulate advanced degrees to compete for law-school positions, and law schools increasingly hire candidates with multiple advanced degrees to compete in prestige and media rankings. ${ }^{7}$

Finally, our analysis shows that male law professors are far more likely than their female counterparts to hold PhDs, but male professors are also far more likely than their female counterparts to be employed by top-tier law schools when they do not hold PhDs. These findings are consistent with other research on gender and employment in academia, ${ }^{8}$ including

\footnotetext{
"Part of our paper's title and the term "pod people" refer to two science-fiction films, both titled Invasion of the Body Snatchers, the original released in 1956, the remake in 1978. For more details, see the Internet Movie DataBase. (http://www.imdb.com/title/tt0049366/?ref =ttpl_pl tt describing the 1956 movie, last viewed April 13, 2016; http://www.imdb.com/title/tt0077745/ describing the 1976 move, last viewed April 13, 2016).

${ }^{7}$ Because surveys of academic reputation, like LSAT scores and post-graduation outcomes, are a key component of the influential U.S. News and World Report law-school rankings, law schools (especially, but not only, the most prestigious ones) may be competing for faculty with PhDs much like they compete for students with high LSAT scores and for strong relationships with the law firms who hire those students (See William D. Henderson \& Andrew P. Morriss, Student Quality as Measured by LSAT Scores: Migration Patterns in the U.S. News Rankings Era, 81 Ind. L. J., 163 (2006) (rankings competition forces law schools across all tiers to compete with students with high LSAT scores); Andrew P. Morris \& William D. Henderson, Measuring Outcomes: Post-Graduation Measures of Success in the U.S. News \& World Report Law School Rankings, 83 Ind. L. J., 791 (2008) (law schools seek to maximize each post-graduation placement to compete in rankings)).

${ }^{8}$ See, e.g., Donna K. Ginther \& Shulamit Kahn, Women in Economics: Moving Up or Falling off the Academic Ladder, 18 J. of Economic Perspectives (2004); Stephen Ceci, Donna Ginther, Shulamit Kahn \& Wendy Williams, Women in Academic Science: A Changing Landscape, 15 Psychological Science in the Public Interest, 75, 141 (2014) (while the gender gap among doctoral degree recipients has been shrinking for decades, and in some disciplines reversing in recent years, particularly in non-STEM (science, technology, engineering and math) fields,
} 
research that finds that when evaluating job candidates, universities do not give female professors equal credit for equal credentials. ${ }^{9}$ The gender gap in the stratification of law faculty across the law-school prestige hierarchy indicates that even though the training of legal academics has changed, patterns of inequality in achievement have persisted.

In Part I of this Article, we explain our methods and why we focus our study on tenured and tenure-track professors. In Part II, we present our empirical findings, identifying temporal trends in the educational backgrounds of law professors overall, as well as trends in law professors' educational backgrounds by law-school prestige and law-professor gender. In Part III, we discuss the import of these findings for ongoing debates about interdisciplinarity and the autonomy of law, as well as inequality in the legal academy.

women continue to be significantly underrepresented among professors in virtually all fields, especially among tenured faculty).

${ }^{9}$ Heather Sarsons, Gender Differences in Recognition for Group Work (forthcoming 2016) (finding that female economists receive less credit than male economists for co-authored publications when being considered for promotion to tenure, especially for publications that include both a male and a female author; this finding is not explained by any first author preference, because in economics authors are listed alphabetically). 


\section{Methodology}

We study tenure-track professors in American law schools because they are among the most elite in an already elite profession. In 2012 , law faculty constituted less than $1 \%$ of the more than 1.2 million active lawyers in the U.S., while tenured or tenure-track law faculty constituted a little more than $0.5 \%$ of lawyers. ${ }^{10}$ As elites among elites, law professors influence the professional training of the next generation of lawyers and public officials (many are or were lawyers), the development of legal doctrine and public policy, and the public understanding of the law and its consequences. As Fisher and Bowen conclude, law professors "are instrumental in shaping the careers of the U.S.'s most powerful individuals [and] are the incubators of ideas affecting law and society." ${ }^{11}$

Law professors stand at the intersection of the law school and the rest of the university: some have credentials that match those of practicing lawyers (JDs), others have credentials that match those of academics in other fields (PhDs), while still others have "hybrid" credentials that combine those of practicing lawyers with those of academics in other fields (joint JD-PhD degrees or JDs and PhDs earned separately). Some observers have argued that the increasing number of law professors with PhDs (with or without JDs) fundamentally alters the relationship between law schools and other parts of universities by eroding the autonomy of law, making the law more susceptible to influence from other disciplines. ${ }^{12}$ But sociological research on academic training and institutional logics suggests that law schools are not likely to import the "alien" cultures and practices of the arts and sciences into the legal academy in a wholesale fashion, but instead will develop hybrid systems by selectively combining elements of the

\footnotetext{
${ }^{10}$ The number of lawyers is from the American Bar Association's "National Lawyer Population by State," for 2012 (http://www.americanbar.org/resources for lawyers/profession statistics.html); the number of law professors and the number of tenure-track law professors is from our own calculations using the 2011-12 Directory of Law Teachers published by the American Association of Law Schools.

${ }^{11}$ Bruce D. Fisher \& Paul Bowen, The Law School Compensation Systems at Three Top Quartile State Law Schools: Factors Correlating Law Professors' Salaries and Suggestions, 19 N. III. U. L. Rev., 671, 675 (1999).

${ }^{12}$ For a list of critics, see supra n. 1. On autonomy in academia more generally, see Pierre Bourdieu, Homo Academicus (1988) (analyzes conflicts in French academics between those who have social power (administrators) and those who have expert power (researchers), as well as between old, established disciplines such as history and philosophy, and newer, less legitimate disciplines such as psychology and sociology).
} 
disciplinary logic of the arts-and-science system and adapting them to the doctrinal legal logic of the law-school system. ${ }^{13}$

To assess trends in law professors' academic backgrounds and in so doing, get some purchase on the extent to which law's autonomy has been eroded by the rise of interdisciplinarity, where in the legal academy that erosion has been most pronounced, and the impact of interdisciplinarity on stratification within the legal academy, we used data-science methods to compile richly detailed and comprehensive data covering law professors' educational histories, personal attributes, and careers. These data cover all accredited law schools in the United States, so they will allow us to describe the entire field of legal education and scholarship and to trace temporal patterns in rise of faculty who received graduate training outside the legal academy.

\section{A. Population}

Our study population is all tenure-track law professors who worked in fully accredited American law schools in the 2011-12 academic year. ${ }^{14}$ To identify members of our research population, we turned to the 2011-12 Directory of Law Teachers (hereafter DLT). ${ }^{15}$ The DLT, published by the American Association of Law Schools (hereafter AALS), contains complete biographical information about every law professor at every fully accredited law school.

\footnotetext{
${ }^{13}$ Eleanor D. Westney, Imitation and Innovation: The Transfer of Western Organizational Patters to Meiji Japan (1987); Douglas Guthrie, Dragon with a Three-Piece Suit: The Emergence of Capitalism in China (1997); Amy Binder, For Love and Money: Organizations' Creative Responses to Multiple Institutional Logics, 36 Theory and Society, 547 (2007); Elizabeth Popp Berman, Explaining the Move to the Market in U.S. Academic Science: How Institutional Logics Can Create Change without Institutional Entrepreneurs, 41 Theory and Society, 261 (2012) (new or external models of organization are not adopted wholesale, but rather selectively, and they are combined with models of organization already in place to create hybrid systems).

${ }^{14}$ There were 195 fully accredited law schools operating that academic year. We excluded four from analysis: the Judge Advocate General's School of the US Army, which draws faculty exclusively from among military officers, and three Puerto Rican schools, University of Puerto Rico, Inter American and Pontifical Catholic University. The applicant pool for faculty positions in these four schools is very different from the applicant pool for other accredited law schools. There were also six provisionally accredited schools: LaVerne, Charleston, Charlotte, Elon, Drexel, and University of Massachusetts-Dartmouth. We excluded these schools from the analysis as well because there was little information available about their rankings or their faculty.

${ }^{15}$ There were 11,334 individuals listed in the DLT that academic year, of whom 11,071 worked at the 191 fully accredited schools we analyzed.
} 
To ensure that our study population includes only tenure-track law professors, we used titles listed in the DLT. While this data source does not identify tenure-track status directly, several scholars have explained that the titles "assistant professor," "associate professor," and "professor" usually denote tenure-track status. ${ }^{16}$ We limited our study to law professors with those titles. We refined our focus by excluding two groups of professors: those who taught exclusively legal research and writing courses or clinical, trial, or appellate advocacy courses, as well as those who held law library appointments. Most faculty in the excluded groups lack tenure-track status; even when faculty in the excluded groups do have that status, their credentials tend to differ greatly from those of other faculty, and they tend to be drawn from a different hiring pool. ${ }^{17}$ For the same reasons, we also excluded visiting professors and faculty who hold dean positions, such as dean, vice dean, assistant dean, or associate dean. The former positions are temporary - either equivalent to short-term post-doctoral fellowships in arts-and-science departments or held by faculty visiting for short periods from another institution where they have permanent appointments - while the latter involve responsibilities and selection criteria that are very different from those involved in selecting tenured and tenure-track law-school faculty. ${ }^{18}$ After making these exclusions, the final study population includes 6,710 law professors. We analyzed the entire study population.

\section{B. Data Sources}

The $D L T$ is the primary source for most variables. Every year since 1922 , the AALS has published a directory containing biographical sketches of full-time faculty and professional staff working at all member and fee-paid law schools in the United States. ${ }^{19}$ According to the AALS, the $D L T$ is "the most widely used 'desk-book' of deans and law teachers," and the association

\footnotetext{
${ }^{16}$ See, e.g., Donna Fossum, Law Professors: A Profile of the Teaching Branch of the Legal Profession, 1980 Am. Bar Found. Res. J., 501, 528-538 (1980); Elyce H. Zenoff \& Jerome A. Barron, So You Want to Be a Law Professor?, $12 \mathrm{~J}$. L. \& Educ., 397 (1988); Merritt \& Reskin supra n. 2.

${ }^{17}$ See Elyce H. Zenoff \& Kathryn V. Lorio, What We Know, What We Think We Know, and What We Don't Know about Women Law Professors, 25 Ariz. L. Rev., 869, 871-72 (1983); Borthwick \& Schau, supra n. 2.

${ }^{18}$ In excluding faculty with dean titles, we follow Hersch \& Viscusi supra $n$. 3.

${ }_{19}$ Publication of the DLT was suspended between 1943 and 1945.
} 
will continue to publish the directory yearly for the foreseeable future. ${ }^{20}$ It has been used to map the demography and educational backgrounds of law professors in several studies. ${ }^{21}$ We used the $D L T$ for the 2011-12 academic year, the most recent available online in machinereadable form. The $D L T$ includes each individual law teacher's name, current position and school, as well as a biographical sketch provided by each individual, which usually contains the individual's birthdate, gender, education, professional work history, markers of distinction (e.g., Phi Beta Kappa, Order of the Coif), subjects taught, and memberships in professional and academic associations. In cases where an individual did not provide complete information on his or her educational background in the $D L T$, we obtained the missing information from the pertinent law school's website or from additional web searches.

\section{Preparing the Data for Analysis}

We downloaded the $D L T$ as a raw text file in ASCII format ${ }^{22}$ from Hein Online through the University of California, Berkeley, Law Library. ${ }^{23}$ The $D L T$ is a rich source of historical and current biographical information on law professors, and can be a rich source of data for scholars interested in law professors and their career trajectories. But the semi-structured format of the $D L T$ (many terms, such as abbreviations for job titles and for names of educational institutions, vary across law professors) makes it difficult to extract data in a format usable for researchers. The length of one year of the DLT alone (in 2011-12, there were over 11,000 individual records on law professors) makes hand coding an improbable method for extracting comprehensive data from the text and reconciling differences across professors in

\footnotetext{
${ }^{20}$ See http://www.aals.org/about/publications/, last accessed April 6, 2016.

${ }^{21}$ See, e.g., Fossum, supra n. 16 (used data for the 1975-76 academic year); Borthwick \& Schau, supra n. 2 (data for the 1988-89 academic year); Merritt \& Reskin, supra n. 2 (data for the 1990-91 academic year); Redding, supra n. 2 (data for the 2000-01 academic year).

${ }^{22}$ ASCll stands for American Standard Code for Information Interchange. Because computers can only understand numbers, to analyze character data (e.g., letters such as a or b, or characters such as @ or \&), characters must be translated to a special machine-readable code. ASCIl is the most commonly used code of this sort.

${ }^{23}$ See http://heinonline.org/HOL/Welcome (last visited April 6, 2016. Behind a paywall, LawCat, the catalog of the Law Library at the University of California, Berkeley, links directly to these archives. See

http://lawcat.berkeley.edu/ (last visited April 6, 2016).
} 
how information is recorded. That is why previous research using this data source either focused on a small number of law schools in the top tier ${ }^{24}$ or relied on teams of research assistants to code the data by hand, a process that can take several years, even when the analysis is limited to new hires. ${ }^{25}$

To transform all of the $D L T^{\prime}$ s raw text strings into a form that could be read by computer programs, and then turn these strings into variables that could be used for statistical analysis, we used Python, a flexible computer language that can handle large quantities of textual data and that is often used in data science. Our Python scripts automatically extracted usable data from the $D L T$ 's raw text and created a cross-sectional dataset containing one observation per law professor covering demographic information, educational background, employing law school, title held, courses taught, marks of distinction, consultantships, memberships in professional or academic societies, published books, awards, and an identification number unique to each professor. Because this process is entirely automated, when subsequent years of the $D L T$ become available on Hein Online, these scripts can be easily used to extract data from them and create a longitudinal dataset (containing one observation per law professor per year) or new cross-sectional datasets. Moreover, this process can flexibly recode information, such as abbreviations for job titles and names of educational institutions, so as to create variables that can be reliably compared between professors at any point in time and over time within professors.

After processing, the file had scattered misspelled or missing information. We cleaned the data by reviewing and, where appropriate, correcting each observation that contained any incongruent or clearly mistaken value for any variable (e.g., where the value for gender was "Northwestern"). With the help of a research assistant, we also reviewed and manually

\footnotetext{
${ }^{24}$ For example, Hersch \& Viscusi, supra n. 3 (analyzed the 26 law schools ranked highest by the U.S. News \& World Report); McCrary, Milligan, \& Phillips, supra n. 3 (analyzed the 34 law schools ranked highest by the U.S. News \& World Report).

${ }^{25}$ For example, Merritt \& Reskin, supra n. 2 ("Over the years, many research assistants contributed to the database analyzed in this Article," n. *).
} 
corrected observations that contained missing values for educational background variables. These reviews and corrections were made first by looking up the relevant professor's biographical sketch in the raw $D L T$ text file. For individuals who did not provide complete educational background information in the $D L T$, we obtained the missing information from their curricula vitae or résumés posted on their current law schools' websites, or, as a last resort, on the their personal websites or vocational social media websites, such as Linkedln. The resulting dataset can be easily imported into various statistical programs (e.g., Excel, Stata, SAS) or programming languages (e.g., R, Python). The dataset can be used on its own or merged with other data, such as law-school rankings, for a variety of analyses.

\section{Measures: Law Professors}

Academic training. We created a series of dichotomous indicators for educational background: whether or not the focal law professor held (1) a bachelor's degree (BA, $A B, B S E$, etc.), (2) a Juris Doctor degree or the equivalent (JD or LLB), (3) a bachelor or master of law degree (BCL, LLM, or MJur), (4) a doctor of the science of law degree (JSD, SJD, LLD, JCD, DCL, or MSBL), (5) a non-professional master's degree (MA, MS, MPhil, MSL, MJ, JSM, etc.), or a professional (non-law) master's degree or doctorate (MBA, MD, MEng, MPP, etc.), and (6) a non-professional doctorate (PhD, DLS, or DPhil). Each dichotomous indicator was set to one if the focal law professor had the focal degree and zero otherwise. We also coded the year each type of degree was earned. When a law professor had more than one degree within a category (e.g., two non-professional master's degrees), we used the last (most recent) year.

After examining the data to assess the distribution of educational backgrounds across these categories, we created a series of dichotomous indicators to capture each law professor's educational background: (1) less than bachelor's degree, (2) bachelor's degree but no advanced degree, (3) bachelor's plus non-law master's degree, (4) bachelor's plus law degree (either JD or LLB, including any advanced law degree such as SJD or JSD), (4) bachelor's plus law degree plus non-law master's degree, (5) bachelor's plus law degree plus PhD (may include a 
non-law master's degree), (6) bachelor's plus PhD but no law degree (may include a non-law master's degree). ${ }^{26}$ We also assessed the incidence of joint JD-PhD training, with a dichotomous indicator variable if the professor's PhD year was within two years of his or her JD, LLM, or JSD year. ${ }^{27}$

Gender. We determined the gender of each law professor from the professor's selfdesignation in the $D L T$. Professors are offered the opportunity to designate their gender, but they do not have to do so. Almost half of the professors in our study population $(3,042 / 6,710)$ did not list their gender. For professors who did not designate their gender, we relied on their first names. To map first names onto gender, we used data from the Social Security Administration on the frequency with which first names are given to men and women in the US. Specifically, we used the "National Data on the relative frequency of given names in the population of US births where the individual has a Social Security Number" for the year 1953, because it was the mean and median birth year in the study population. ${ }^{28}$ Table 1 , which shows the distribution of names for women and men, reveals that a small number of common names conferred that year (those given to 1,000 or more babies) accounted for the vast majority of births, while a large number of rare names (those given to 250 or fewer babies) accounted for a small fraction of births. This table also shows examples of names in each category.

\footnotetext{
${ }^{26}$ Non-law master's degrees include master's degrees conferred by law schools to non-lawyers; e.g., Yale's Master of Studies in Law. These degrees cannot, by design, substitute for any part of the curriculum leading to a law degree and they are not open to people who hold law degrees.

${ }^{27}$ We tried several thresholds for timing of joint degrees. Using the exact year, within one year, or within three years yields very similar results as using within two years.

${ }^{28}$ These data were retrieved from http://www.ssa.gov/oact/babynames/limits.html by clicking on the link for national data.
} 
Table 1: Distribution of Names in the 1953 Social Security Administration Birth Names File

\begin{tabular}{crrrr}
\hline & $\begin{array}{r}\text { Number of } \\
\text { Babies with } \\
\text { Name }\end{array}$ & $\begin{array}{r}\text { Number } \\
\text { of Names }\end{array}$ & Examples & $\begin{array}{r}\text { Number of } \\
\text { People }\end{array}$ \\
\hline Male & $\geq 1,000$ & 214 & Robert, James, Neil & $1,742,659$ \\
Names & 250 to 1,000 & 237 & Aaron, Troy, Galen & 117,254 \\
& $\leq 250$ & 3,887 & Rory, Morgan, Bruno & 109,594 \\
\hline \multirow{2}{*}{ Female } & Total & 4,338 & & $1,969,507$ \\
Names & 250 to 1,000 & 257 & Mary, Linda, Deborah & $1,571,271$ \\
& $\leq 250$ & 5,942 & Aileen, Erin, Maude & 146,837 \\
& Total & 6,494 & & $1,880,326$ \\
\hline
\end{tabular}

We used two thresholds to automatically code names as male or female. Names that were frequently (1,000 times or more) given to one gender and rarely or never (250 times or fewer) given to the other gender were coded as denoting the more frequent gender. ${ }^{29}$ All other names - (i) those given 1,000 times or more to one gender and more than 250 times to the other, (ii) those given fewer than 1,000 times to one gender and more than 250 times to the other, and (iii) those given fewer than 1,000 times to one gender and 250 times or fewer to the other - were coded as ambiguous. ${ }^{30}$ To make our procedure clear, Table 2 charts these coding decisions. Applying these classification rules to the 1953 names data, most law professors had names that were either unambiguously male or unambiguously female, so we were able to use this categorization scheme to automatically code gender for 2,583 of the 3,042 law professors who did not list their gender. We then looked up the remaining 459 law professors' biographies on their current law school and personal websites, and designated gender based on the pronouns used in the biographies. Using this method, we were able to code gender for all but six professors in the dataset, whom we could not locate or, if we did locate them, could not determine their gender based on the pronouns in their biographies.

\footnotetext{
${ }^{29}$ Names with frequencies above the higher threshold $(1,000)$ for one gender and below the lower threshold $(250)$ for the other gender included some very common male names that were sometimes given to girls (e.g., James, Jason, Bob, Robert) and some very common female names that were sometimes given to boys (e.g., Carmen, Ronda, Phyllis, Sandy).

${ }^{30}$ Most names derived from languages other than English (e.g., Jasmín, Yasheng, Alya, Olivier) were in category (iii) above and so were coded as ambiguous.
} 
Table 2:

Coding Scheme for Gender Based on First Name Frequency in Social Security Administration Names File

\begin{tabular}{|c|c|c|c|c|}
\hline \multirow{5}{*}{ 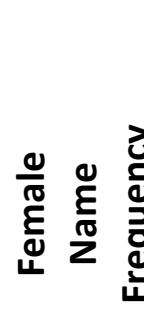 } & \multirow{5}{*}{$\begin{array}{c}\geq 1,000 \\
250 \text { to } 1,000 \\
\leq 250\end{array}$} & \multicolumn{3}{|c|}{ Male Name Frequency } \\
\hline & & $\geq 1,000$ & 250 to 1,000 & $\leq 250$ \\
\hline & & Ambiguous & Ambiguous & Female \\
\hline & & Ambiguous & Ambiguous & Ambiguous \\
\hline & & Male & Ambiguous & Ambiguous \\
\hline
\end{tabular}

E. Measures: Educational Institutions

Law-school prestige. Although generally faculty members in law, as in other academic fields, seek appointments at the most prestigious institutions, previous research has shown that faculty with non-standard educational backgrounds - specifically those with doctorate degrees outside the law - are both more likely to be hired by and more likely to seek positions in prestigious law schools. ${ }^{31}$ Prestigious law schools can better afford to pay for professors' extra credentials (which require considerable time and money to acquire) and prestigious law schools have more need for marks of distinction, such as advanced degrees held by their faculty. ${ }^{32}$

To assess the relationship between faculty educational background and law-school prestige, we identified the law school that conferred each professor's law degree. We used several measures of law-school prestige. To begin, we used data from the US News \& World Report (hereafter USNWR) rankings of law schools to create a subjective ordinal measure of law-school prestige. These rankings are controversial, having been attacked by observers on multiple grounds. ${ }^{33}$ Nevertheless, they dominate the field and have strong effects on law

\footnotetext{
${ }^{31}$ Hersch \& Viscusi, supra n. 3 (even among law schools ranked in the top 26 by USNWR, faculty with PhDs are more heavily concentrated in law schools ranked in the top 13).

${ }^{32}$ Randall Collins, The Credential Society: An Historical Sociology of Education and Stratification (1979) (academic degrees are credentials that signal value in labor markets; both individuals and employing organizations compete over such credentials); Eliot Freidson, Professional Powers: A Study in the Institutionalization of Formal Knowledge (1986) (credentials are essential to professions such as law, medicine, and academia because credentials underpin professionals' rights, powers, and prestige).

${ }^{33}$ E.g., Nancy B. Rapaport, Ratings, Not Rankings: Why U.S. News and World Report Shouldn't Want to be Compared to Time and Newsweek - or The New Yorker, Ohio St. L. J., 1097, 1098-1100 (1999) (“objective" inputs to the rankings, such as LSAT scores, are not "good indicator[s] of quality" because they don't capture faculty teaching and research quality or school support for students); Richard A. Posner, Law School Rankings, 81 Ind. L. J.,
} 
school administrators, prospective students, and recruiters. ${ }^{34}$ Specifically, we created a measure of law-school prestige that divides law schools into six hierarchical categories: (1) the 14 top-ranked law schools, according to USWNR, ${ }^{35}(2)$ the schools ranked 15 to $25,{ }^{36}(3)$ the schools ranked 26 to $50,{ }^{37}(4)$ the schools ranked 51 to $100,,^{38}(5)$ the schools ranked 101 to $150,{ }^{39}$ and (6) the schools ranked 151 to $191 .^{40}$ This variable allows us to assess qualitative differences between law schools that are in different prestige categories.

Next, we used two other measures, one subjective and one objective. The subjective measure was based on the reputational component of the USNWR ranking ("the peer score"), which captures perceived prestige in the eyes of legal scholars and is most germane to our analysis. This is measured on a 1 to 5 scale, with 1 indicating "marginal" and 5 indicating "outstanding. For the objective measure, we used data from USNWR and the ABA-LSAC Official Guides to Law Schools to determine the median LSAT scores for each school's entering class in

13 (2006) (the weights assigned to the components of these rankings are arbitrary); Jeffrey Evans Stake, The Interplay Between Law School Rankings, Reputations, and Resource Allocation: Ways Rankings Mislead, 81 Ind. L. J., 229 (2006) (rankings push schools to over-attend to highly weighted components and to tweak aspects of the admission process in ways that do not improve education quality).

${ }^{34}$ Michael Sauder \& Ryon Lancaster, Do Rankings Matter? The Effect of U.S. News \& World Report Rankings on the Admissions Process of Law Schools, 40 L. \& Soc. Rev., 105 (2006); Wendy Nelson Espeland \& Michael Sauder, Rankings and Reactivity: How Public Measures Recreate Social Worlds, 113 Am. J. of Sociology, 1; Michael Sauder, Interlopers and Field Change: The Entry of U.S. News into the Field of Legal Education, 53 Administrative Science Quarterly, 209 (2008); Michael Sauder \& Wendy Nelson Espeland, The Discipline of Rankings: Tight Coupling and Organizational Change, 74 Am. Sociological Rev., 63 (2009) (law-school rankings have substantial effects on the decisions of student applicants, the decisions of admissions committees, and the decisions of law firms that hire law graduates. In response to these rankings, law schools gave greater weight to LSAT scores in admissions (to raise median LSAT scores, which strongly affect these rankings), increased spending on marketing and advertising (to reach out to more applicants with higher LSAT scores), reallocated resources from need- to merit-based scholarships (to attract applicants with higher LSAT scores), and shifted career-service efforts from counseling to raising post-graduation employment numbers (those numbers also affect rankings)).

${ }^{35}$ The 14 most prestigious law schools according to the USNWR for the 2011-12 academic year were: Yale, Harvard, Stanford, Columbia, NYU, Chicago, Berkeley, Michigan, Penn, Georgetown, Cornell, UVA, Duke and Texas.

${ }^{36}$ Because of a five-way tie at 22, there were 12 schools in the 15-25 category in 2012.

${ }^{37}$ There were 31 schools in the $26-50$ category in 2012. Seven schools were tied at 49 . In addition, we included U.C. Irvine in the 26-50 category because, although U.C. Irvine was unranked in 2012 (having been formed in 2009), it was ranked $30^{\text {th }}$ in prestige for 2016, when it appeared in the U.S. News rankings for the first time. ${ }^{38}$ There were 48 schools in the 51-100 category in 2012, because 11 schools were tied at 94 .

${ }^{39}$ There were 52 schools in the 101-150 category in 2012, because 7 schools were tied at 150 .

${ }^{40}$ There were 34 schools in the last category. 
the fall of $2011 .^{41}$ This is measured on a scale of 120 to $180 .^{42}$ Median LSAT scores and reputation scores were highly correlated (the correlation was 0.95).

F. Methods of Analysis

We conducted cross-tabular analyses, counting the number of law professors in each set of categories: law-professor educational background, law-professor cohort (based on year of highest degree), law-school prestige, and law-professor gender. We tested the statistical significance of reported associations ${ }^{43}$ using the chi-squared test, or where cell counts were small, the Fisher's exact test; these are the standard measures of association for nominal categorical variables. ${ }^{44}$ To assess the statistical significance of associations between different measures of law-school prestige, as well as to assess associations between law-school prestige, on the one hand, and law-professor educational background, on the other, we used the Spearman rank-order correlation, a measure of association that is appropriate for ordinal variables (rank-ordered categories) or a mixture of ordinal and continuous variables. ${ }^{45}$

\footnotetext{
${ }^{41}$ Seymour Warkov \& Joseph Zelan, Lawyers in the Making (1965); Fossum, supra n. 16 (LSAT scores have proven to be a reliable indicator of school prestige).

${ }^{42}$ Median LSAT scores come from http://www.Isac.org/Isacresources/publications/official-guide-archives (last visited April 6, 2016).

${ }^{43}$ Statistical significance means that the observed pattern of data reflects differences that are very unlikely to be due to chance or measurement error. By convention, results are considered to be statistically significant if the probability ( $p$-value) is less than 0.05 , meaning that the finding would have occurred by chance or miscalculation due to measurement error fewer than five times out of one hundred. Although we analyze the entire population of tenured and tenure-track law professors, we assess the statistical significance of the patterns we uncover in the data in order to assess the potential of patterns emerging due to measurement error.

${ }^{44}$ For a discussion of the benefits of Fisher's exact test over the chi-squared test and the monotonicity requirement of Fisher's exact test, see Alan Agresti \& Barbara Finlay, Statistical Methods for the Social Sciences, $4^{\text {th }}$ Edition (2009). Using a Fisher's exact test instead of a chi-squared test did not render statistically insignificant results statistically significant for any of the results reported here.

${ }^{45}$ There are other possible measures of association for such data, notably Kendall's tau-b and Goodman and Kruskall's gamma. On the former, see Maurice Kendall, A New Measure of Rank Correlation, 30 Biometrika, 81 (1938); on the latter, see Leo A. Goodman \& William H. Kruskal, Measures of Association for Cross Classifications, $49 \mathrm{~J}$. of the Am. Statistical Assn, 732 (1954). Both alternative measures yield results that are consistent with the results we discuss here.
} 


\section{Results}

A. Law Professors' Educational Background

In our study population (tenured and tenure-track law professors, excluding visiting professors, faculty with dean positions, faculty with law library appointments, faculty who taught exclusively legal research and writing courses or clinical, trial, or appellate advocacy courses), there were 6,710 law professors in the 2011-12 academic year. Table 3 shows the percentage of law professors with various advanced degrees. The overwhelming majority (97.33\%) held JDs or the equivalent (LLB), or advanced law degrees (LLM, JSD, SJD). Just over one in eight held PhDs and over one-third (34.14\%) held master's degrees from outside law schools (either arts-and-science departments or other professional schools). The fraction of law professors with PhDs was somewhat larger than the fraction reported in studies that used data gathered at earlier points in time: only 5\% of law professors in the 1988-89 academic year had PhDs outside the law, ${ }^{46}$ only $10 \%$ of law professors hired between 1996 and 2000 (who can be expected to be at the forefront of new educational trends) had PhDs. ${ }^{47}$ This indicates that the rise of faculty trained outside the law continued after the turn of the century. This conclusion is bolstered by research on a subset of law professors in recent years: based on reports to a legal academy blog (PrawfsBlawg), 21\% of tenure-track hires by all American law schools from 2011 to 2015 (who can be expected to be at the forefront of new educational trends) had PhDs. ${ }^{48}$

\footnotetext{
${ }^{46}$ Merritt \& Reskin, supra n. 2.

${ }^{47}$ Redding, supra n. 2.

${ }^{48}$ LoPucki, supra n. 3.
} 


\section{Table 3: Advanced Degrees Held by Tenured and Tenure-Track Law Professors}

\begin{tabular}{lrr}
\hline Type of Advanced Degree & $\begin{array}{r}\text { Number of } \\
\text { Law Professors }\end{array}$ & $\begin{array}{r}\text { Percentage of } \\
\text { the Population }\end{array}$ \\
\hline None ${ }^{49}$ & 3 & $0.04 \%$ \\
Master's & 2,291 & $34.14 \%$ \\
JD & 6,531 & $97.33 \%$ \\
PhD & 883 & $13.16 \%$ \\
\hline Total & 6,710 & $100 \%$ \\
\hline
\end{tabular}

The categories "master's", "JD", and "PhD" are not mutually exclusive: an individual could appear in all three categories. The category "JD" includes all faculty with advanced law degrees: JDs, LLBs, LLMs, SJDs, and JSDs. The category "none" includes faculty with no advanced degrees.

Table 4 breaks down the distribution of law professors in greater detail, showing the complex variety of law-professor educational backgrounds. Most notably, it reveals that the oft-feared (or celebrated) incursion of faculty whose education took place entirely outside the legal academy is miniscule, accounting for only $2.63 \%$ of law professors $(0.55 \%$ with bachelor's plus non-law master's, $2.07 \%$ with bachelor's plus PhDs but no master's). Among law professors with PhDs, the vast majority $(744 / 883$, or $87.66 \%)$ also had JDs. Faculty with JDs and PhDs constituted just over one-tenth (11.09\%) of all law professors. Among law professors with non-law master's degrees (but no PhDs), an even larger majority $(1,371 / 1,408$, or $97.37 \%)$ also had JDs. Faculty with JDs and non-law master's degrees constituted just over one-fifth (20.43\%) of all law professors.

\footnotetext{
${ }^{49}$ One law professor, Joel Garreau, did not hold a bachelor's degree or any higher degree. A former reporter for The Washington Post, he was a tenured law professor at Arizona State University who taught courses on law and culture. Two law professors, Lisa Griffin and Gordon Smith, held bachelors' degrees but no higher degrees. Professor Griffin was a former practicing litigator (she was admitted to the Bar after being a law clerk for several years and passing the Bar exam) who was a tenured law professor at Pace University and published extensively on criminal procedure. Professor Smith was an intellectual-property management expert who held a tenured law professor position at the University of New Hampshire.
} 
Table 4: Detailed Educational Background of Tenured and Tenure-Track Law Professors

\begin{tabular}{lrr}
\hline Degree(s) Held & $\begin{array}{r}\text { Number of } \\
\text { Law Professors }\end{array}$ & $\begin{array}{r}\text { Percentage of } \\
\text { the Population }\end{array}$ \\
\hline Less than bachelor's & 1 & $0.01 \%$ \\
Bachelor's only & 2 & $0.03 \%$ \\
Bachelor's + master's & 37 & $0.55 \%$ \\
Bachelor's + JD (but no master's) & 4,416 & $65.81 \%$ \\
Bachelor's + master's + JD & 1,371 & $20.43 \%$ \\
Bachelor's + JD + PhD & 744 & $11.09 \%$ \\
Bachelor's + PhD (but no JD) & 139 & $2.07 \%$ \\
\hline Total & 6,710 & $100 \%$ \\
\hline
\end{tabular}

The categories "bachelor's + JD + PhD" and "bachelor's + PhD but no JD" include both those with and without master's degrees outside the law.

These data indicate that law professors with advanced academic training outside the law are unlikely to import totally "foreign" academic norms and practices that will reduce the autonomy of law schools and make them isomorphic to the rest of the academy. Instead, such faculty are likely, based on their joint training in law and other fields, to support "hybrid" academic norms and practices - selecting only a subset of elements that are congruent with traditional law-school culture and practices while rejecting others, and adapting the selected elements to fit law schools rather than adopting them as is. In a sense, faculty with JDs and advanced degrees outside the law epitomize the unique and somewhat insular position of American law schools at the intersection of academia and legal practice. ${ }^{50}$

To understand how this pattern developed, we analyzed temporal trends, distinguishing among law professors employed in the 2011-12 academic year by cohort, defined in terms of the year of their highest degree. ${ }^{51}$ Because this analysis focused on the contrast between and

\footnotetext{
${ }^{50}$ Olufunmilayo, Morriss \& Henderson, supra n.1 at 24 (tying law professors with PhDs to the "peculiar hybrid form" of American law schools that is both "unmoored from the practicing bar" - a result of the historical association of law schools with research universities and the relative stability and inertia of the legal profession throughout the $20^{\text {th }}$ century - and "curiously removed from scholarship norms generally prevalent at academic research institutions" - a result of law schools' professional status and (until recently) outsize revenues as the gatekeepers to a lucrative vocation). How the recent precariousness of the legal profession, and the shrinking revenues of law schools, will affect the hybrid or liminal nature of legal education in America is a question that should be of great interest for future research.

${ }^{51}$ The downside of this analysis is that for earlier cohorts, we are missing data on faculty who entered in those years but left the focal law school before the 2011-12 academic year because they retired or died, moved to
} 
confluence of JDs and PhDs, we excluded from the analysis all law professors without either one or both of those degrees: one without any degree, two with only bachelors' degrees, and thirty-seven with masters' degrees but no law degrees. We also excluded law professors whose highest degree date we were unable to determine, a total of 202. Thus, the population analyzed here included 6,468 professors.

Table 5, which shows these temporal trends, reveals some expected results, but also some surprising ones. As expected, the fraction of faculty with JDs but no other advanced degrees outside the law declined steadily and substantially, from over three-quarters (76.67\%) for the $1938-70$ cohort to over half $(54.38 \%)$ for the $2001-11$ cohort. The fraction of those with JDs plus master's degrees outside the law initially rose, from $15.61 \%$ for the $1938-70$ cohort to $25.28 \%$ for the $1981-90$ cohort, then declined to just over $20 \%$ for the $1991-2000$ and $2001-11$ cohorts (20.85\% and $20.59 \%$, respectively). The fraction of law professors with JDs and PhDs rose steadily and substantially, from $4.55 \%$ for the $1938-70$ cohort to almost one-quarter (23.94\%) for the $2001-11$ cohort. It is notable that among law professors in the $2001-11$ cohort, the fraction with JDs and PhDs outstripped the fraction with JDs and masters' degrees (23.94\% to $20.59 \%)$. Finally, although the fraction of law professors with PhDs but not JDs in the 193870 cohort was almost as large as the fraction with PhDs and JDs (3.18\% and $4.55 \%$, respectively), PhDs without JDs became increasingly rare, declining to just $1.08 \%$ for the 2001 11 cohort, which is less than one-twentieth of the fraction of faculty with PhDs and JDs in that cohort (23.94\%)..

different law schools, or left the legal academy for positions elsewhere. Such differential selection out of cohorts is unlikely to bias our analysis of the rise of law professors with PhDs because such faculty are likely to have had similar rates of mobility as faculty without PhDs. But it might affect our analysis of gender and interdisciplinarity, since previous research has shown that compared to male faculty, female faculty are more subject to attrition from tenure-track academic positions and are less likely to rise up through the ranks (e.g., Robyn Marschke, Sandra Laursen, Joyce McCarl Nielsen, \& Patricia Rankin, Demographic Inertia Revisited: An Immodest Proposal to Achieve Equitable Gender Representation among Faculty in Higher Education, $78 \mathrm{~J}$. Higher Educ. 1 (2007) (revealing that in a research-intensive university, female faculty are less likely to be promoted to tenure and more likely to leave tenure-track positions than their male counterparts); Marc Goulden, Mary Ann Mason, \& Kate Frasch, Keeping Women in the Science Pipeline, 638 Annals of the Am. Acad. of Political \& Social Sci. 141 (2011) (finding that in the natural sciences, married female faculty with children are less likely to be promoted to tenure than their male counterparts)). 
Table 5: Temporal Trends in Law Faculty Educational Background

\begin{tabular}{lrrrrr}
\hline & \multicolumn{5}{c}{ Cohort (Year of Highest Degree) } \\
\hline Advanced Degree(s) Held & $\mathbf{1 9 3 8 - 7 0}$ & $\mathbf{1 9 7 1 - 8 0}$ & $\mathbf{1 9 8 1 - 9 0}$ & $\mathbf{1 9 9 1 - 2 0 0 0}$ & $\mathbf{2 0 0 1 - 1 1}$ \\
\hline \multirow{2}{*}{ JD only } & 506 & 1,142 & 1,038 & 1,036 & 552 \\
& $(76.67 \%)$ & $(70.45 \%)$ & $(65.28 \%)$ & $(65.49 \%)$ & $(54.38 \%)$ \\
JD + master's & 103 & 298 & 402 & 330 & 209 \\
& $(15.61 \%)$ & $(18.38 \%)$ & $(25.28 \%)$ & $(20.86 \%)$ & $(20.59 \%)$ \\
JD + PhD & 30 & 129 & 121 & 197 & 243 \\
& $(4.55 \%)$ & $(7.96 \%)$ & $(7.61 \%)$ & $(12.45 \%)$ & $(23.94 \%)$ \\
PhD but no JD & 21 & 52 & 29 & 19 & 11 \\
& $(3.18 \%)$ & $(3.21 \%)$ & $(1.82 \%)$ & $(1.20 \%)$ & $(1.08 \%)$ \\
\hline Total & 660 & 1,621 & 1,590 & 1,582 & 1,015 \\
\hline
\end{tabular}

Numbers in parentheses represent the percentage of faculty in a cohort that falls within each education category. The temporal trends for JD only, JD + PhD, and PhD but no JD are each statistically significant, each having a $p$-value $<0.01$ using a chisquared test.

Taken together, these data reveal a very different story from that imagined by those who bemoaned (or applauded) the arrival of PhD-trained faculty in law schools. Instead of professors with JDs being displaced by those with PhDs only, faculty with JDs became increasingly likely to hold PhDs. Moreover, among recent cohorts, faculty with JDs and master's degrees gave way to those with JDs and PhDs. In sum, these trends suggest that faculty hiring in U.S. law schools has become a sort of credentialing contest, as the job candidates who are deemed the most qualified for these valuable positions possess a larger number of ever-higher advanced degrees, and more of those degrees include both advanced law degrees and advanced degrees outside the law. ${ }^{52}$

A sizeable fraction of law professors with both JDs and PhDs earned joint degrees. Table 6 compares the number of joint and non-joint JD-PhD combinations across cohorts. ${ }^{53}$ The fraction of joint JD-PhD combinations increased slightly over time, from one in six in the 193870 cohort to just over one in five for the 1981-90, 1991-2000, and 2001-11 cohorts, but this

\footnotetext{
${ }^{52}$ On the value of academic degrees as job-market credentials, see Collins, supra n. 32.

${ }^{53}$ We coded a law professor as having joint JD-PhD training if the professor's PhD year was within two years of his or her JD, LLM, or JSD year. Using the same year, within one year, or within three years yielded very similar results to those shown here.
} 
increase is not statistically significant. This pattern indicates that while the number of law professors with degrees from joint JD-PhD programs has steadily increased over the years, these programs were not a driver of the overall increase in the number of law professors with both JDs and PhDs. Instead, law professors with PhDs earned them separately from their JDs. Three-fifths percent of law professors with both JDs and PhDs earned their JD first (429/710 or $60.42 \%)$, while slightly more than a third earned their PhD first (250/710 or $35.21 \%$ ), and less than one-twentieth earned the two degrees the same year (31/710 or $4.37 \%)$. This tendency also increased over time. Whereas among professors with both degrees from cohorts prior to 1991, slightly fewer earned their JDs first (114/244 or 46.7\%) than earned their PhDs first (123/244 or $50.4 \%)$, among such professors from the two most recent cohorts, those who earned their JDs first outpaced those who earned their PhDs first by a ratio of more than 2 to 1 (122/189 or $64.55 \%$ compared to $58 / 189$ or $30.69 \%$ for the $1991-2000$ cohort; and $193 / 277$ or $69.68 \%$ compared to $69 / 277$ or $24.9 \%$ for the $2001-11$ cohort). These results indicate that law professors were generally trained in traditional legal scholarship before acquiring advanced training in disciplines outside the law.

Table 6: Temporal Trends in Law Faculty with JDs and PhDs: Joint versus Non-Joint Degrees

\begin{tabular}{lrrrrr}
\hline & \multicolumn{5}{c}{ Cohort (Year of Highest Degree) } \\
\hline Degree Relationship & $\mathbf{1 9 3 8 - 7 0}$ & $\mathbf{1 9 7 1 - 8 0}$ & $\mathbf{1 9 8 1 - 9 0}$ & $\mathbf{1 9 9 1 - 2 0 0 0}$ & $\mathbf{2 0 0 1 - 1 1}$ \\
\hline \multirow{2}{*}{ Joint degree } & 5 & 17 & 26 & 39 & 52 \\
\multirow{2}{*}{ Not joint degree } & $(16.67 \%)$ & $(13.28 \%)$ & $(22.03 \%)$ & $(20.10 \%)$ & $(21.67 \%)$ \\
& 25 & 111 & 92 & 155 & 188 \\
Total & $(83.33 \%)$ & $(86.72 \%)$ & $(77.97 \%)$ & $(79.90 \%)$ & $(78.33 \%)$ \\
\hline
\end{tabular}

Numbers in parentheses represent the percentage of faculty in a cohort that falls within each education category. The difference in the proportions of joint JD-PhD degrees and not joint JD-PhD degrees over time is not statistically significant ( $p$-value of 0.3383 using a chi-squared test).

In sum, these data show a persistent increase in law-school faculty with advanced degrees outside the law, especially PhDs. Most of the faculty with PhDs also held JDs, and the 
likelihood that faculty members with PhDs also held JDs increased dramatically from the oldest to the newest cohorts.

B. Relationships Between Law-Professor Educational Background and Law-School Prestige To investigate the correspondence between the prestige of the law schools at which professors work and professors' educational background, we cross-tabulated professors' education and the ranking tier of their current law schools (based on USNWR prestige rankings) in Table 7. This table reveals four clear trends. First, the percentage of law-school faculty who held JDs but no other higher degrees increases as we descend the prestige hierarchy, from just over half (51.71\%) of faculty in the top 14 law schools to just under three-quarters $(72.11 \%)$ of faculty in the bottom tier of law schools. ${ }^{54}$ Second, the percentage of law-school faculty who held JDs and non-law master's degrees (but not PhDs) is approximately constant across the prestige hierarchy at one-fifth of faculty; the maximum, $21.63 \%$, is seen in law schools ranked $101-150$ and the minimum, $18.29 \%$, is seen in law schools ranked $15-25 .{ }^{55}$ Third, the percentage of law-school faculty who held PhDs - either with or without JDs - declines steadily as we descend the prestige hierarchy, from over one-quarter of faculty in the top 14 schools (20.66\% PhDs and JDs, 7.42\% PhDs without JDs) to just over one-twentieth of faculty in the lowest tier of law schools (5.88\% PhDs and JDs, $0.10 \%$ PhDs without JDs). ${ }^{56}$ Fourth, among faculty with PhDs, the ratio of those with JDs to those without JDs rises steadily as we descend the prestige hierarchy, from almost 3:1 in the top tier of law schools to 58:1 in the lowest tier. ${ }^{57}$

\footnotetext{
${ }^{54}$ This trend is statistically significant: the chi-squared test yields a p-value less than 0.001 .

${ }^{55}$ Differences in the proportion of JD/MAs across the prestige groups is not statistically significant: the chi-squared test yields a p-value of 0.4192 .

${ }^{56}$ This decline is statistically significant: the chi-squared test yields a p-value of less than 0.001 .

${ }^{57}$ This increase is statistically significant: the Fisher's exact test yields a p-value of less than 0.001 .
} 
Table 7: Faculty Educational Background and Current Law-School Prestige

\begin{tabular}{|c|c|c|c|c|c|c|c|}
\hline \multirow{2}{*}{$\begin{array}{l}\text { Law-School } \\
\text { Prestige Group } \\
\text { (USNWR Score) }\end{array}$} & \multicolumn{7}{|c|}{ Law Professor Degree(s) Held } \\
\hline & $\begin{array}{r}\text { Less than } \\
\text { BA }\end{array}$ & BA only & $\mathrm{BA}+\mathrm{MA}$ & $\begin{array}{r}B A+J D \\
\text { (no } M A)\end{array}$ & $\begin{array}{r}B A+J D \\
+M A\end{array}$ & $\begin{array}{r}\text { BA + JD } \\
+ \text { PhD }\end{array}$ & $\begin{array}{r}\mathrm{BA}+\mathrm{PhD} \\
\text { (no JD) }\end{array}$ \\
\hline \multirow{3}{*}{ Top 14} & 0 & 0 & 7 & 453 & 170 & 181 & 65 \\
\hline & (0.00\%) & $(0.00 \%)$ & $(0.80 \%)$ & (51.71\%) & (19.41\%) & (20.66\%) & (7.42\%) \\
\hline & $(0.00 \%)$ & $(0.00 \%)$ & (18.92\%) & (10.26\%) & $(12.40 \%)$ & $(24.33 \%)$ & $(46.76 \%)$ \\
\hline \multirow{3}{*}{$15-25$} & 0 & 0 & 2 & 286 & 92 & 101 & 22 \\
\hline & $(0.00 \%)$ & $(0.00 \%)$ & $(0.40 \%)$ & (56.86\%) & (18.29\%) & (20.08\%) & $(4.27 \%)$ \\
\hline & (0.00\%) & (0.00\%) & (5.41\%) & (6.48\%) & (6.71\%) & (13.58\%) & (15.83\%) \\
\hline \multirow{3}{*}{$26-50$} & 1 & 0 & 3 & 714 & 212 & 151 & 25 \\
\hline & (0.09\%) & $(0.00 \%)$ & $(0.27 \%)$ & (64.56\%) & (19.17\%) & $(13.65 \%)$ & (2.26\%) \\
\hline & $(100 \%)$ & (0.00\%) & (8.11\%) & (16.17\%) & (15.46\%) & (20.30\%) & (17.99\%) \\
\hline \multirow{3}{*}{$51-100$} & 0 & 0 & 9 & 1140 & 353 & 160 & 19 \\
\hline & $(0.00 \%)$ & $(0.00 \%)$ & (0.54\%) & $(67.82 \%)$ & $(21.00 \%)$ & (9.52\%) & $(1.13 \%)$ \\
\hline & (0.00\%) & (0.00\%) & (24.32\%) & (25.82\%) & (25.75\%) & (21.51\%) & $(13.67 \%)$ \\
\hline \multirow{3}{*}{$101-150$} & 0 & 2 & 7 & 1112 & 337 & 93 & 7 \\
\hline & (0.00\%) & $(0.13 \%)$ & (0.45\%) & (71.37\%) & (21.63\%) & (5.97\%) & (0.44\%) \\
\hline & (0.00\%) & (100\%) & (18.92\%) & (25.18\%) & (24.58\%) & (12.50\%) & (5.04\%) \\
\hline \multirow{3}{*}{$150+$} & 0 & 0 & 9 & 711 & 207 & 58 & 1 \\
\hline & (0.00\%) & $(0.00 \%)$ & (0.91\%) & (72.11\%) & (21.00\%) & (5.88\%) & (0.10\%) \\
\hline & (0.00\%) & (0.00\%) & (24.32\%) & (16.10\%) & (15.10\%) & (7.80\%) & (0.72\%) \\
\hline Total & 1 & 2 & 37 & 4,416 & 1,371 & 744 & 139 \\
\hline
\end{tabular}

Numbers in parentheses represent the percentage of faculty in each law-school prestige group that falls within each education category. Italicized numbers in parentheses represent the percentage of faculty in each education category that falls within each law-school prestige group.

Together, these trends indicate that there is a clear and strong association between law professors holding PhDs and the prestige of their current law school, one that cannot be due to measurement error. Faculty with PhDs, with or without JDs, were far more likely to be employed in more prestigious law schools, while faculty with JDs but not PhDs were far more likely to be employed in less prestigious law schools. These findings are similar to those from a recent study on a random sample of faculty at the top 26 law schools: in 2009-10, 24\% of faculty in that sample had PhDs. ${ }^{58}$ In our data, which cover 2011-12, when we combine the top

${ }^{58}$ LoPucki, supra n. 3. 
two tiers of law schools taken together (schools ranked 1 to 25 ), we find that $26.76 \%$ of tenured and tenure-track faculty had PhDs, $20.45 \%$ with PhDs and JDs, $6.31 \%$ with PhDs but no JDs. Together, the findings from our study and the earlier study indicate that even at the top ranks of law-school prestige, where the incursion of PhD-trained faculty had been the most pronounced, the growth of this subgroup of faculty continued.

To assess the sensitivity of our analysis to measuring law-school prestige using tiers, we calculated associations between faculty education with two continuous measures of law-school prestige - the USNWR reputational component and the median LSAT score. For the reputational component, the Spearman rank-order correlation with faculty education was 0.17. For the median LSAT score, the correlation was 0.16. Together, these results indicate that faculty with advanced degrees were more likely to work in more prestigious law schools. These results also bolster our confidence in the conclusions we drew from the analysis using ordered categories (tiers) for law-school prestige.

Such strong associations between law-school prestige and law-professor educational background are not surprising, as we have evidence from previous research that faculty with PhDs are highly concentrated in more prestigious law schools. ${ }^{59}$ What is surprising, however, is the extent to which faculty with PhDs have entered less prestigious law schools. Among law schools ranked 51-100, over one-tenth (10.65\%) of faculty had PhDs. Even among law schools ranked in the bottom two tiers, a sizeable minority of faculty had PhDs: $6.41 \%$ among law schools ranked 101-150 and 5.98\% among law schools ranked 150 and beyond. The continued rise of faculty with PhDs outside the law indicates that law school hiring practices have become credential wars, as candidates with the "best" credentials are increasingly likely to win these

\footnotetext{
${ }^{59}$ Hersch \& Viscusi, supra n. 3 (even among law schools ranked in the top 26 by USNWR, faculty with PhDs are more heavily concentrated in law schools ranked in the top 13); LoPucki, supra n. 3 (42\% of hires $2010-15$ in the top quartile held PhDs, compared with $17 \%$ in the second quartile, $13 \%$ in the third quartile, and $11 \%$ in the fourth quartile); McCrary, Milligan, \& Phillips, supra n. 3 (in 2011-12, 28\% of tenure-track professors in the 34 law schools ranked highest by the USNWR had PhDs).
} 
valued positions. ${ }^{60}$ Finally, the spread of faculty with PhDs outside the law to even the lowest tier of law schools indicates that these credential wars are becoming ever more pervasive.

To pinpoint temporal trends, we focused on law faculty with PhDs and cross-tabulated year of highest degree with the prestige of the current law school (based on USNWR prestige rankings). These results are shown in Table 8. Cohorts do not differ significantly in terms of in which prestige groups law professors with PhDs (both with and without JDs) work. ${ }^{61}$ The consistency across cohorts is especially evident for cohorts with years of highest degree after $1970 .^{62}$ And this finding persists across the prestige hierarchy. In the 14 most prestigious law schools, the share of law professors with PhDs declines only slightly from $28.73 \%$ for the 1971 1980 cohort to $26.77 \%$ for the $2001-11$ cohort. $^{63}$ In the law schools ranked $1-25$ in prestige, the share of law professors with PhDs varies within a narrow range, between $38.78 \%$ (for the 197180 cohort) and $43.98 \%$ percent (for the $1991-2000$ cohort). ${ }^{64}$ Similarly, in law schools ranked 26-100 in prestige, the share of law professors with PhDs varies between $37.04 \%$ (for the 19912000 cohort) and $43.65 \%$ (for the $1971-1980$ cohort), while in law schools ranked lower than 100 in prestige, the share of law professors with PhDs varies between $16.00 \%$ (for the $1981-90$ cohort) and $18.98 \%$ (for the 1991-2000 cohort). ${ }^{65}$ Even when we include the 1938-1970 cohort, the percentage of law professors with PhDs at each of the six prestige groups in Table 8 is not statistically different across cohorts. ${ }^{66}$

\footnotetext{
${ }^{60}$ On the rise of academic degrees as job-market credentials, see Collins, supra n. 32.

${ }^{61}$ None of the cohorts are statistically significantly different from each other in their distribution of law professors with PhDs across the different prestige groups, with chi-squared or Fisher's exact tests yielding $p$-values in excess of 0.11 in each case.

${ }^{62}$ The differences among cohorts after 1970 have p-values in excess of 0.54 in each case using chi-squared tests.

${ }^{63}$ This decline, having a p-value of 0.95 using the chi-squared test, is not statistically significant.

64 This variation, having a p-value of 0.95 using the chi-squared test, is not statistically significant.

${ }^{65}$ Neither of these two variations is statistically significant, each having a p-value of 0.95 (the former using a chisquared test and the latter using a Fisher's exact test).

${ }^{66}$ P-values are above 0.19 in each case, using chi-squared or Fisher's exact tests. When we exclude 1938-1970 cohort, the $\mathrm{p}$-values are above 0.82 in each case, again using chi-squared or Fisher's exact tests.
} 
Table 8: Law Professors with PhDs: Degree Cohort versus Current Law-School Prestige

\begin{tabular}{lrrrrr}
\hline \multirow{2}{*}{ Prestige Group } & \multicolumn{5}{c}{ Cohort (Year of Highest Degree) } \\
\cline { 2 - 6 } & $\mathbf{1 9 3 8 - 7 0}$ & $\mathbf{1 9 7 1 - 8 0}$ & $\mathbf{1 9 8 1 - 9 0}$ & $\mathbf{1 9 9 1 - 2 0 0 0}$ & $\mathbf{2 0 0 1 - 1 1}$ \\
\hline \multirow{2}{*}{ Top 14 } & 22 & 52 & 43 & 58 & 68 \\
& $(43.14 \%)$ & $(28.73 \%)$ & $(28.67 \%)$ & $(26.85 \%)$ & $(26.77 \%)$ \\
$15-25$ & 4 & 20 & 21 & 37 & 37 \\
& $(7.84 \%)$ & $(11.05 \%)$ & $(14.00 \%)$ & $(17.13 \%)$ & $(14.57 \%)$ \\
$26-50$ & 12 & 35 & 34 & 37 & 53 \\
& $(23.53 \%)$ & $(19.34 \%)$ & $(22.67 \%)$ & $(17.13 \%)$ & $(20.87 \%)$ \\
$51-100$ & 5 & 44 & 28 & 43 & 53 \\
& $(9.80 \%)$ & $(24.31 \%)$ & $(18.67 \%)$ & $(19.91 \%)$ & $(20.87 \%)$ \\
$101-150$ & 5 & 17 & 16 & 25 & 28 \\
& $(9.80 \%)$ & $(9.39 \%)$ & $(10.67 \%)$ & $(11.57 \%)$ & $(11.02 \%)$ \\
$150+$ & 3 & 13 & 8 & 16 & 15 \\
& $(5.88 \%)$ & $(7.18 \%)$ & $(5.33 \%)$ & $(7.41 \%)$ & $(5.91 \%)$ \\
\hline Total & 51 & 181 & 150 & 216 & 254 \\
\hline
\end{tabular}

Numbers in parentheses represent the percentage of faculty with PhDs in a cohort that falls within each prestige group.

In sum, Table 8 suggests that the distribution of law professors with PhDs across the law school hierarchy in the most recent cohort - heavily concentrated among top-tier schools to be sure, but also fairly widely dispersed across other tiers - is not a recent development. We can surmise that as more and more law professors with PhDs have hit the market, law schools at each tier have kept pace with hiring their share of such candidates.

One reason for the positive association between $\mathrm{PhD}$ education and law-school prestige may be that law professors with both JDs and PhDs may have been trained primarily in the most prestigious law schools. Previous research confirms the widely held belief that law professors in general come overwhelmingly from the most elite law schools. ${ }^{67}$ But, like other analyses of the backgrounds of law professors, this research has become quite dated. Moreover, previous research does not address whether law professors with JDs and PhDs also

\footnotetext{
${ }^{67}$ Donna Fossum, Law Professors: A Profile of the Teaching Branch of the Legal Profession, $1980 \mathrm{Am}$. Bar Found. Res. J. 501, 507 Table 2 (1980) (finding that 58.9\% of law professors teaching in 1975-76 held JDs from 20 elite law schools); Borthwick \& Schau, supra n. 3, 227 Table 27 (1991) (finding that half of the professors listed in the 198889 DLT held JDs from the 13 top law schools and that another $12.9 \%$ came from the next-ranked 12 law schools).
} 
come disproportionately from elite schools. An increasing fraction of law schools offer PhD degrees - in the 2015-16 academic year, 51 schools offer PhD degrees that are joint with some other unit in their university (with PhD training administered by outside departments); a few offer PhDs administered by law schools themselves. ${ }^{68}$ The increasing prevalence of PhD programs associated with law schools calls into question whether the same relationship between degrees from elite law schools and faculty positions in elite law schools applies to professors with both degrees, and whether any such relationship has persisted or abated over time. ${ }^{69}$ To settle this question, we now investigate law professors with both JDs and PhDs, calculating the percentage of such professors who held law degrees from each law-school prestige group, as well as cross-tabulating the prestige group of the degree-granting law school with the year of highest degree.

Table 9, which tabulates the distribution of law professors with both JDs and PhDs by the degree-granting law school prestige group, shows that law professors with both JDs and PhDs were more likely to come from the most elite law schools than are law professors in general. About three quarters of law professors with both JDs and PhDs earned their law degrees at one of the 14 most prestigious law schools, compared with just under $70 \%$ of all law professors. But this prestige classification obscures the concentration of prestige. A more finegrained inspection reveals that almost half of the law professors with both JDs and PhDs who earned their law degrees at the 14 most prestigious law schools did so at the two most prestigious schools: either Yale (139/548 or $25.36 \%)$ or Harvard $(123 / 548$ or $22.45 \%){ }^{70}$

\footnotetext{
${ }^{68}$ The number of joint JD-PhD programs comes from startclass.com, a well-known online directory of educational institutions. Available at http://law-schools.startclass.com/d/e/JD-_-_PhD (last visited April 6, 2016). Yet for all but a handful of these programs, law schools play a supporting role; the exceptions are the University of California-Berkeley, the University of Washington, Vanderbilt University, and Yale University (Calvin Morrill, Rachel Cichowski, Bill Maurer, Laura Beth Nielsen, and Tom Tyler, Final Report, Subcommittee on Graduate Programs. Law \& Society Association (http://www.lawandsociety.org/docs/Grad Schools.pdf; last viewed July 5, 2016)).

${ }^{69}$ It is plausible that the acquisition of an additional advanced degree, especially a PhD, increasingly levels the playing field, allowing graduates of less elite law schools to compete for faculty positions at more elite law schools, which would otherwise be unavailable to them.

${ }^{70}$ This continues the trend noted by Redding, supra n. 2, and accords with the findings of McCrary, Milligan, \& Phelps, supra n. 3.
} 
Conversely, the set of all law schools that were not ranked in the top 25 in terms of prestige accounted for just $18.00 \%$ of law degrees held by law professors with both JDs and PhD, and more than a quarter of those law degrees (39/133 or $29.32 \%$ ) were from foreign schools, which were not ranked by USNWR.

Table 9: Law Professors with JDs and PhDs by Degree-Granting Law-School Prestige

\begin{tabular}{lrr}
\hline Prestige Group & $\begin{array}{r}\text { Number of } \\
\text { Law Professors }\end{array}$ & $\begin{array}{r}\text { Fraction of the } \\
\text { Population }\end{array}$ \\
\hline Top 14 & 548 & $74.15 \%$ \\
$15-25$ & 58 & $7.85 \%$ \\
$26-50$ & 54 & $7.31 \%$ \\
$51-100$ & 35 & $4.74 \%$ \\
$101-150$ & 9 & $1.22 \%$ \\
$150+$ & 1 & $0.14 \%$ \\
Foreign Schools & 34 & $4.60 \%$ \\
\hline Total & 739 & $100 \%$ \\
\hline
\end{tabular}

In addition, Table 10, which cross-tabulates the degree-granting law school prestige group and cohort, suggests that the virtual stranglehold that the most elite law schools have on producing law faculty with both JDs and PhDs has increased over time, notwithstanding the increasing number of law schools that are associated with PhD programs. The percentage of professors with both JDs and PhDs who graduated from the 14 most elite law schools increased by $15.63 \%$ from the $1938-1970$ cohort to the $1991-2000$ cohort (from $68.00 \%$ to $78.62 \%$;

$78.63 / 68.00=1.1563)$, and then increased again by $6.98 \%$ percent from that cohort to the 2001 11 cohort (from $78.62 \%$ to $84.12 \%$; $84.12 / 78.63=1.0698$ ), a temporal trend that is statistically significant. $^{71}$

${ }^{71} \mathrm{~A}$ chi-squared test yields a $\mathrm{p}$-value of 0.03913 . 
Table 10: Law Professors with JDs and PhDs: Degree Cohort versus Degree-Granting Law-School Prestige

\begin{tabular}{lrrrrr}
\hline \multirow{2}{*}{ Prestige Group } & \multicolumn{5}{c}{ Cohort (Year of Highest Degree) } \\
\cline { 2 - 6 } & $\mathbf{1 9 3 8 - 7 0}$ & $\mathbf{1 9 7 1 - 8 0}$ & $\mathbf{1 9 8 1 - 9 0}$ & $\mathbf{1 9 9 1 - 2 0 0 0}$ & $\mathbf{2 0 0 1 - 1 1}$ \\
\hline \multirow{2}{*}{ Top 14 } & 17 & 94 & 80 & 147 & 196 \\
& $(68.00 \%)$ & $(74.02 \%)$ & $(72.07 \%)$ & $(78.61 \%)$ & $(84.12 \%)$ \\
$15-25$ & 3 & 15 & 10 & 11 & 15 \\
& $(12.00 \%)$ & $(11.81 \%)$ & $(9.01 \%)$ & $(5.88 \%)$ & $(6.44 \%)$ \\
$26-50$ & 3 & 9 & 11 & 15 & 13 \\
& $(12.00 \%)$ & $(7.09 \%)$ & $(9.91 \%)$ & $(8.02 \%)$ & $(5.58 \%)$ \\
$51-100$ & 1 & 8 & 7 & 12 & 6 \\
& $(4.00 \%)$ & $(6.30 \%)$ & $(6.31 \%)$ & $(6.42 \%)$ & $(2.58 \%)$ \\
$101-150$ & 1 & 1 & 2 & 2 & 3 \\
& $(4.00 \%)$ & $(0.79 \%)$ & $(1.80 \%)$ & $(1.07 \%)$ & $(1.29 \%)$ \\
$150+$ & 0 & 0 & 1 & 0 & 0 \\
& $(0.00 \%)$ & $(0.00 \%)$ & $(0.90 \%)$ & $(0.00 \%)$ & $(0.00 \%)$ \\
\hline Total & 25 & 127 & 111 & 187 & 233 \\
\hline
\end{tabular}

Numbers in parentheses represent the percentage of faculty with PhDs in a cohort that falls within each prestige group.

In sum, the results shown in this subsection indicate that the proliferation of law professors with both JDs and PhDs did not, as the spread of PhD programs in law schools might suggest, increase the diversity of law schools from which faculty earn their law degrees. Instead, law professors with both degrees reproduced the long-established hierarchy among law schools in the matriculation of law faculty. This is another way in which our results suggest that the influx of professors with both JDs and PhDs is a hybrid phenomenon, incorporating past law-school culture and practices (specifically, scrupulous attention to prestige), rather than replacing them with those belonging to external disciplines (where prestige of the degreegranting institution is less salient). The resulting culture and practices are at best described as interdisciplinary, rather than completely foreign. 
C. Relationships Among Law-Professor Gender, Educational Background, and Law-School Prestige

To assess the correspondence between law professors' educational background and their gender, we cross-tabulated data on all law professors whose gender we were able to determine. The population under study includes 6,704 tenured and tenure-track law professors in the 2011-12 academic year; it excludes six law professors for whom we could not determine gender. In this population, $62.60 \%$ were male and $37.40 \%$ were female.

Table 11 shows the cross-tabulation of educational background and gender. Female law professors were slightly (6.17\%) more likely than their male counterparts to have JDs but no other advanced degree $(68.29 \%$ of female versus $64.32 \%$ of male professors; 68.29/64.32=1.0617). Female law professors were also slightly (7.54\%) more likely than their male counterparts to have JDs and master's degrees $(21.38 / 19.88=1.0754)$. In contrast, male law professors were much more likely to have PhDs, either with or without JDs. ${ }^{72}$ The differences were quite large. Male professors were almost one-and-one-half times as likely than female professors to have JDs and PhDs (12.61/8.58=1.4697), and more than twice as likely to have PhDs but not JDs (2.57/1.24=2.0706).

\footnotetext{
${ }^{72}$ McCrary, Milligan, \& Phillips, supra n. 3, found similar patterns of gender differences in educational background among the 34 law schools at the top of the USNWR ranking.
} 
Table 11: Educational Background of Tenured and Tenure-Track Law Professors by Gender

\begin{tabular}{lrrrr}
\hline \multirow{2}{*}{ Degree(s) Held } & \multicolumn{2}{c}{ Number of Law Professors } & \multicolumn{2}{r}{$\begin{array}{r}\text { Percentage of } \\
\text { Each Gender }\end{array}$} \\
\cline { 2 - 5 } & Male & Female & Male & Female \\
\cline { 2 - 5 } & 2 & 1 & $0.04 \%$ & $0.04 \%$ \\
\hline Bachelor's or less & 25 & 12 & $0.60 \%$ & $0.48 \%$ \\
Bachelor's + master's & 2,699 & 1,712 & $64.32 \%$ & $68.29 \%$ \\
Bachelor's + JD (but no master's) & 834 & 536 & $19.88 \%$ & $21.38 \%$ \\
Bachelor's + master's + JD & 529 & 215 & $12.61 \%$ & $8.58 \%$ \\
Bachelor's + JD + PhD & 108 & 31 & $2.57 \%$ & $1.24 \%$ \\
Bachelor's + PhD (but no JD) & 4,197 & 2,507 & $100 \%$ & $100 \%$ \\
\hline Total & & &
\end{tabular}

The difference in educational background between male and female law professors is statistically significant ( $p<0.001$ using Fisher's exact test for count data with simulated $p$-value based on 1,000 replications).

To assess how these patterns emerged, we cross-tabulated law-professor educational background by cohort for both male and female professors. Table 12 shows these results. It reveals that the temporal trends we saw in Table 5 hold for both male and female professors. Among both men and women, there was a steady increase across the cohorts in the number of professors who held both JDs and PhDs (from $4.81 \%$ for the $1938-70$ cohort to $25.89 \%$ for the 2001-11 cohort among men and from $1.75 \%$ to $21.59 \%$ for the same cohorts among women), and a corresponding decrease in the number of professors who held only JDs (from $76.45 \%$ to $53.39 \%$ among men and from $78.95 \%$ to $55.51 \%$ among women). Table 12 also shows that there was a very large increase in the share of female faculty since the first two cohorts, but that that share plateaued at nearly half and has stayed remarkably stable since 1980 . Whereas women represented less than one-tenth of the $1938-70$ cohort $(57 / 660=0.0864)$, and less than three-tenths of the $1971-1980$ cohort $(462 / 1,619=0.2854)$, they represented about $45 \%$ of each of the last three cohorts $(711 / 1,590=0.4472$ for the $1981-90$ cohort; $718 / 1,580=0.4544$ for the 1991-00 cohort; 454/1,014=0.4477 for the 2001-11 cohort). Moreover, while there were far fewer women than men among law professors in the first two cohorts, the educational backgrounds of those women did not differ from the educational backgrounds of their male counterparts. Indeed, in both the $1938-70$ cohort and the $1971-80$ cohort there were no 
statistically significant differences between men and women in the likelihood of holding each type of degree. $^{73}$

Table 12: Temporal Trends in Law Faculty with JDs and PhDs by Gender

\begin{tabular}{|c|c|c|c|c|c|c|}
\hline \multirow{2}{*}{$\begin{array}{l}\text { Advanced } \\
\text { Degree(s) }\end{array}$} & \multirow{2}{*}{ Gender } & \multicolumn{5}{|c|}{ Cohort (Year of Highest Degree) } \\
\hline & & $1938-70$ & $1971-80$ & $1981-90$ & $1991-2000$ & 2001-11 \\
\hline \multirow{4}{*}{ JD only } & \multirow{2}{*}{ Male } & 461 & 812 & 556 & 505 & 299 \\
\hline & & $(76.45 \%)$ & $(70.18 \%)$ & $(63.25 \%)$ & $(58.58 \%)$ & $(53.39 \%)$ \\
\hline & \multirow{2}{*}{ Female } & 45 & 328 & 482 & 530 & 252 \\
\hline & & $(78.95 \%)$ & $(71.00 \%)$ & $(67.79 \%)$ & $(73.82 \%)$ & $(55.51 \%)$ \\
\hline \multirow{4}{*}{ JD + master's } & \multirow{2}{*}{ Male } & 95 & 208 & 210 & 193 & 111 \\
\hline & & $(15.75 \%)$ & $(17.98 \%)$ & $(23.89 \%)$ & $(22.39 \%)$ & $(19.82 \%)$ \\
\hline & \multirow{2}{*}{ Female } & 8 & 90 & 192 & 136 & 98 \\
\hline & & $(14.04 \%)$ & $(19.48 \%)$ & $(27.00 \%)$ & $(18.94 \%)$ & $(21.59 \%)$ \\
\hline \multirow{4}{*}{$J D+P h D$} & \multirow{2}{*}{ Male } & 29 & 95 & 94 & 147 & 145 \\
\hline & & $(4.81 \%)$ & (8.21\%) & (10.69\%) & (17.05\%) & (25.89\%) \\
\hline & \multirow{2}{*}{ Female } & 1 & 34 & 27 & 50 & 98 \\
\hline & & $(1.75 \%)$ & $(7.36 \%)$ & (3.80\%) & $(6.96 \%)$ & $(21.59 \%)$ \\
\hline \multirow{4}{*}{ PhD but no JD } & \multirow{2}{*}{ Male } & 18 & 42 & 19 & 17 & 5 \\
\hline & & $(2.99 \%)$ & (3.63\%) & $(2.16 \%)$ & (1.97\%) & $(0.89 \%)$ \\
\hline & \multirow{2}{*}{ Female } & 3 & 10 & 10 & 2 & 6 \\
\hline & & (5.26\%) & $(2.16 \%)$ & $(1.41 \%)$ & $(0.28 \%)$ & $(1.32 \%)$ \\
\hline Male total & & 603 & 1,157 & 879 & 862 & 560 \\
\hline Female total & & 57 & 462 & 711 & 718 & 454 \\
\hline Total & & 660 & 1,619 & 1,590 & 1,580 & 1,014 \\
\hline
\end{tabular}

Numbers in parentheses represent the percentage of faculty of each gender in each cohort that falls within each education category.

Circa 1980, however, the educational backgrounds of male and female law professors began to diverge. In the 1981-90 cohort, men were almost three times more likely to hold both JDs and PhDs than were women (10.69\% for men versus $3.80 \%$ for women). ${ }^{74}$ In the $1991-2000$

\footnotetext{
${ }^{73}$ None of the differences between the male and female percentages of professors with each type of degree in the 1938-70 and 1971-1980 cohorts is statistically significant. The differences between the genders in the percentage of professors with each type of degree in those cohorts had p-values ranging between 0.1756 (for professors holding PhDs but not JDs in the 1981-90 cohort) and 0.8800 (for professors holding JDs and MAs in the 1938-70), using chi-squared or Fisher's exact tests.

${ }^{74}$ This is a statistically significant result with a $p$-value $<0.01$ using a chi-squared test. The other differences in the 1981-90 cohort were not statistically significant, although the difference in the portion of men $(63.25 \%)$ and women (67.790\%) who held JDs only came close ( $p$-value of 0.06 using a chi-squared test).
} 
cohort, female professors were more than $25 \%$ more likely to hold just JDs $(73.82 / 58.58=1.2602)$, while male professors were almost two-and-one-half times more likely to hold PhDs with JDs $(17.05 / 6.96=2.4497)$ and slightly more than seven times more likely to hold PhDs without JDs $(1.97 / 0.28=7.0357) .{ }^{75}$ This divergence appears to have abated more recently, as none of the gender differences in educational background in the 2001-11 cohort are statistically significant, although the difference in the share of professors with both JDs and PhDs comes close to being significant. ${ }^{76}$ In sum, the stark differences between men and women in educational background that are evident in Table 11 appear to be driven primarily by a disproportionate number of male professors with both JDs and PhDs from the 1981-90 and 1991-2000 cohorts, and a disproportionate number of female professors with just JDs from the 1991-2000 cohort.

These stark differences between male and female law professors' educational backgrounds, in combination with the strong association between law professors' educational backgrounds and school prestige, suggest that male professors will work in more prestigious law schools, and that male professors' superior educational credentials - their far greater likelihood of holding PhDs, with or without JDs - will account for at least some of the gender gap in law-school prestige. To determine whether this inference is valid, we cross-tabulated professor education background and school prestige separately for male and female professors. These results are shown in Table 13. It shows that, as predicted, male law professors disproportionately worked at the top 14 law schools by prestige. The fraction of men in our population (14.63\%) who worked at the 14 most prestigious schools exceeds the fraction of women in our population $(10.34 \%)$ at those schools by over $40 \%(14.63 / 10.34=1.4149)$. This disparity is statistically significant. ${ }^{77}$ Female faculty, conversely, worked disproportionately at

\footnotetext{
${ }^{75}$ All three of these differences are statistically significant, with p-values below 0.01 using a chi-squared test or a Fisher's exact test.

${ }^{76}$ The gender difference in the percentage of professors with both JDs and PhDs in the 2001-11 cohort has a pvalue of 0.1276 using a chi-squared test. The other gender differences in the 2001-11 cohort had $p$-values ranging between 0.5401 and 0.5543 using chi-squared or Fisher's exact tests.

${ }^{77}$ Using a chi-squared test yields a $p$-value $<0.01$.
} 
the least prestigious law schools. Female professors were $25 \%$ more likely than male professors to be employed by schools ranked 150 or lower in terms of prestige, a difference that was statistically significant $(16.76 / 13.38=1.2526) .{ }^{78}$ Men and women in our population were statistically equally likely to work at schools in the middle four prestige groups. ${ }^{79}$

Table 13 (part 1): Law-Professor Educational Background and Current Law-School Prestige by Gender

\begin{tabular}{|c|c|c|c|c|c|c|}
\hline \multirow{2}{*}{$\begin{array}{l}\text { Law-School } \\
\text { Prestige Group }\end{array}$} & \multirow{2}{*}{ Gender } & \multicolumn{5}{|c|}{ Advanced Degree(s) } \\
\hline & & JD Only & $\mathrm{JD}+\mathrm{MA}$ & $\mathrm{JD}+\mathrm{PhD}$ & PhD, no JD & Total \\
\hline \multirow{6}{*}{ Top 14} & \multirow{3}{*}{ Male } & 319 & 116 & 123 & 52 & 610 \\
\hline & & $(11.82 \%)$ & (13.91\%) & $(23.25 \%)$ & $(48.15 \%)$ & $(14.63 \%)$ \\
\hline & & (52.30\%) & (19.01\%) & (20.16\%) & (8.52\%) & (100\%) \\
\hline & \multirow{3}{*}{ Female } & 134 & 53 & 58 & 13 & 258 \\
\hline & & $(7.83 \%)$ & (9.89\%) & $(26.98 \%)$ & (41.94\%) & $(10.34 \%)$ \\
\hline & & $(51.94 \%)$ & $(20.54 \%)$ & $(22.48 \%)$ & $(5.04 \%)$ & $(100 \%)$ \\
\hline \multirow{6}{*}{$15-25$} & \multirow{3}{*}{ Male } & 183 & 55 & 71 & 14 & 323 \\
\hline & & $(6.78 \%)$ & $(6.59 \%)$ & $(13.42 \%)$ & $(12.96 \%)$ & $(7.75 \%)$ \\
\hline & & $(56.66 \%)$ & $(17.03 \%)$ & $(21.98 \%)$ & $(4.33 \%)$ & $(100 \%)$ \\
\hline & \multirow{3}{*}{ Female } & 103 & 37 & 30 & 8 & 178 \\
\hline & & $(6.01 \%)$ & $(6.90 \%)$ & $(13.95 \%)$ & $(25.81 \%)$ & $(7.14 \%)$ \\
\hline & & $(57.87 \%)$ & (20.79\%) & $(16.85 \%)$ & (4.49\%) & $(100 \%)$ \\
\hline \multirow{6}{*}{$26-50$} & \multirow{3}{*}{ Male } & 452 & 132 & 105 & 21 & 710 \\
\hline & & $(16.74 \%)$ & (15.83\%) & (19.85\%) & (19.44\%) & (17.02\%) \\
\hline & & (63.66\%) & (18.59\%) & $(14.88 \%)$ & (2.96\%) & (100\%) \\
\hline & \multirow{3}{*}{ Female } & 262 & 80 & 46 & 4 & 392 \\
\hline & & (15.30\%) & (14.92\%) & $(21.40 \%)$ & $(12.90 \%)$ & $(15.72 \%)$ \\
\hline & & $(66.84 \%)$ & (20.41\%) & (11.73\%) & $(1.02 \%)$ & (100\%) \\
\hline \multirow{6}{*}{$51-100$} & \multirow{3}{*}{ Male } & 679 & 208 & 117 & 14 & 1018 \\
\hline & & $(25.16 \%)$ & (24.94\%) & $(22.12 \%)$ & $(12.96 \%)$ & $(24.41 \%)$ \\
\hline & & $(66.70 \%)$ & (19.99\%) & (11.49\%) & (1.38\%) & (100\%) \\
\hline & \multirow{3}{*}{ Female } & 457 & 145 & 43 & 5 & 650 \\
\hline & & (26.69\%) & (27.05\%) & (20.00\%) & (16.13\%) & (26.06\%) \\
\hline & & (70.31\%) & (22.31\%) & (6.62\%) & $(0.77 \%)$ & (100\%) \\
\hline
\end{tabular}

\footnotetext{
${ }_{78}^{78}$ Using a chi-squared test yields a p-value $<0.01$.

${ }^{79}$ None of the gender differences in the percentage of professors working at schools ranked 15-25, 26-50, 51-100 or 101-150 were statistically significant using chi-squared tests. P-values ranged from 0.14 (for the 26-50 group) to 0.39 (for the $15-25$ group).
} 
Table 13 (part 2):

Law-Professor Educational Background and Current Law-School Prestige by Gender

\begin{tabular}{|c|c|c|c|c|c|c|}
\hline \multirow{2}{*}{$\begin{array}{l}\text { Law-School } \\
\text { Prestige Group }\end{array}$} & \multirow{2}{*}{ Gender } & \multicolumn{5}{|c|}{ Advanced Degree(s) } \\
\hline & & JD Only & $J D+M A$ & $J D+P h D$ & PhD, no JD & Total \\
\hline \multirow{6}{*}{$101-150$} & & 672 & 205 & 68 & 6 & 951 \\
\hline & Male & (24.90\%) & (24.58\%) & (12.85\%) & (5.55\%) & (22.81\%) \\
\hline & & (70.66\%) & (21.56\%) & (7.15\%) & $(0.63 \%)$ & (100\%) \\
\hline & Female & 440 & 132 & 25 & 1 & 598 \\
\hline & $F \epsilon$ & (25.70\%) & (24.63\%) & (11.63\%) & (3.23\%) & (23.98\%) \\
\hline & & (73.58\%) & $(22.07 \%)$ & $(4.18 \%)$ & $(0.17 \%)$ & $(100 \%)$ \\
\hline \multirow{6}{*}{$150+$} & Mla & 394 & 118 & 45 & 1 & 558 \\
\hline & Thiare & (14.60\%) & (14.15\%) & (8.51\%) & (0.93\%) & (13.38\%) \\
\hline & & (70.61\%) & (21.15\%) & $(8.06 \%)$ & $(0.18 \%)$ & $(100 \%)$ \\
\hline & & 316 & 89 & 13 & 0 & 418 \\
\hline & ale & $(18.46 \%)$ & (16.60\%) & (6.05\%) & $(0.00 \%)$ & $(16.76 \%)$ \\
\hline & & (75.60\%) & (21.29\%) & (3.11\%) & (0.00\%) & (100\%) \\
\hline Total & & 4,411 & 1,370 & 744 & 139 & 6,664 \\
\hline
\end{tabular}

Numbers in parentheses represent the percentage of faculty in the focal gender in the focal prestige group that falls within each education category. Italicized numbers in parentheses represent the percentage of faculty in the focal gender in the focal education category that falls within each law-school prestige group.

But do the superior educational backgrounds of men (namely their far higher rates of holding PhDs, with or without JDs) account for their higher likelihood of being employed by the most prestigious law schools, as hypothesized? Surprisingly, they do not. At the 14 most prestigious schools, women were slightly more likely than men to hold PhDs and JDs (22.48\% or $58 / 258$ for women versus $20.16 \%$ or $123 / 610$ for men), but this difference is not statistically significant. ${ }^{80}$ And at those schools, men were somewhat more likely than women to hold PhDs but not JDs ( $8.52 \%$ or $52 / 610$ for men versus $5.04 \%$ or $13 / 258$ for women), but again this difference is not statistically significant. ${ }^{81}$ Male and female faculty with both JDs and PhDs were statistically equally likely to work at one of the 14 most prestigious law schools $(26.98 \%$

\footnotetext{
${ }^{80}$ Using a chi-squared test yields a $\mathrm{p}$-value of 0.50 .

${ }^{81}$ Using a chi-squared test yields a p-value of 0.10 .
} 
for women versus $23.25 \%$ for men). ${ }^{82}$ The same holds for male and female faculty with PhDs but without JDs (41.94\% for women versus $48.15 \%$ for men). ${ }^{83}$ By contrast, male professors with JDs and no other advanced degrees were more than $50 \%$ more likely to work at one of the 14 most prestigious schools than were women with just a law degree $(11.82 / 7.83=1.5096)$. This difference is statistically significant. ${ }^{84}$ Similarly, male professors with JDs and MAs were more than $40 \%$ more likely to work at the most prestigious group of law schools than were women with the same credentials $(13.91 / 9.89=1.4065)$, another statistically significant difference. ${ }^{85}$ It is this overrepresentation of men with the fewest academic credentials among the top 14 schools (and not men's higher likelihood of holding PhDs, with or without JDs) that accounts most for why men were so overrepresented among faculty in the most prestigious law schools. A big part of this story is that a large portion of male professors at these most prestigious law schools came from early cohorts, ${ }^{86}$ in which there were far fewer female faculty and far fewer faculty with PhDs (with or without JDs). ${ }^{87}$ Therefore, the disproportionate number of male law professors with weaker educational credentials at the most prestigious law schools may be a legacy of past hiring practices. ${ }^{88}$ But this still begs the question, if it is not their better

\footnotetext{
${ }^{82}$ The difference between the two percentages is not statistically significant: a chi-squared test yields a p-value of 0.33 .

${ }^{83}$ The difference between the two percentages is not statistically significant: a chi-squared test yields a p-value of 0.68 .

${ }^{84}$ Using a chi-squared test yields a $\mathrm{p}$-value $<0.01$. Female law professors with just JDs, however, are $26 \%$ more likely than men with just JDs to teach at schools ranked 150 and below in prestige $(18.46 / 14.60=1.264)$, also a statistically significant result, with a $p$-value $<0.001$ using a chi-squared test.

${ }^{85}$ Using a chi-squared test yields a $p$-value $=0.03$.

${ }^{86} 259$ out of 603 (or $42.95 \%$ ) male law professors at the 14 most prestigious law schools for whom we have cohort data come from the 1938-1970 and 1971-1980 cohorts. Another 114 (or 18.9\%) come from the 1981-1990 cohort. ${ }^{87}$ In the 14 most prestigious law schools, women represented $11.20 \%(14 / 125)$ of law professors from the 19381970 cohort and $23.71 \%(46 / 194)$ from the $1971-1980$ cohort. In contrast, $34.00 \%$ (132/388) of law professors at those schools from the 1981-1990 and 1991-2000 cohorts were female, as were $42.11 \%$ (64/152) from the 20012011 cohort. Moreover, $17.60 \%$ (22/125) of law professors from the 1938-1970 cohort at the most prestigious law schools held PhDs (with or without JDs), compared to $27.10 \%$ (158/583) of such law professors from the 1971$1980,1981-1990$, and 1991-2000 cohorts, and $40.00 \%$ (68/170) of such professors from the 2001-2011 cohort. It is possible that the increase in the fraction of law professors who are women and the increase in the fraction of law professors who hold both JDs and PhDs are related. It may be that the opening of faculty positions to women supercharged the credentials wars in the legal academy, spurring the growth of law professors with both JDs and PhDs.

${ }^{88}$ Among the last two cohorts (1991-2000 and 2001-2011) at the 114 most prestigious law schools, the share of professors with just JDs is virtually identical for men (43.04\% or $99 / 230)$ and for women $(43.85 \%$ or $57 / 130)$.
} 
credentials, why is that men outnumber women among the most recent cohort of law professors?

\section{Discussion}

What do our empirical analyses teach us about the spread of interdisciplinarity, as embodied by legal scholars who are trained in external disciplines such as statistics, economics, and history, in the legal academy? Have law schools really been invaded by "body snatchers" or "pod people" - academics with alien knowledge and values who have been displacing scholars with traditional legal knowledge and values? Or have law schools actually seen more of the same - specifically, new faculty with similar legal training to older faculty? And has the rise of interdisciplinarity among law professors undermined or reinforced the traditional prestige hierarchy in the legal academy? In this section, we summarize our findings and offer some observations about the impact of these findings.

\section{A. Law Professors}

Our analysis showed that in the 2011-12 academic year, faculty with JDs but no other advanced degrees constituted just under two-thirds of all tenured and tenure-track law-school professors. Just over one-third of tenured and tenure-track faculty had master's degrees outside the law, while just over one-eighth had PhDs. Notably, almost all faculty with PhDs also had JDs, as did almost all faculty with master's degrees. These findings indicate that while just over one-third of law-school faculty have been exposed to the culture, traditions, and specialized knowledge and methods of external disciplines (mostly in the humanities and social sciences) through their master's or PhD training, the vast majority of them have also been exposed to the culture, traditions, and specialized knowledge and methods of the traditional legal academy, through their JD training. Moreover, for most law professors, training in law preceded training in outside disciplines. 
Research in sociology has shown that the cultures and practices of all communities, including academic communities in law schools and arts-and-science departments, are created through everyday interactions: people continually produce and reproduce shared understandings of what should (not) be thought, said, and done, and it is these shared understandings that stabilize people's social worlds. ${ }^{89}$ Culture, in the form of beliefs, values, and norms, "anchors" peoples' actions, while actions relentlessly recreate culture. ${ }^{90}$ Most germane to the analysis of law professors' educational backgrounds is that the cultures and practices of academics and professionals - the institutionalized understandings, or logics, that underpin their preferences and actions - are strongly shaped by socialization during formal education, when norms about what "typical" and "good" members of their communities are and do, and how they do those things, are inculcated into students. ${ }^{91}$ Among the professions, it is in medical school that students come to adopt a rationalized view of the human body, learning to categorize human physiology and anatomy; to view illness, pain, and deformity as problems in medical responsibility; and to put aside emotional, empathetic, and moralized reactions to human suffering. ${ }^{92}$ Similarly, it is in law school that students come to adopt a rationalized view of the law, learning "how to think like a lawyer," ${ }^{93}$ which involves acquiring

\footnotetext{
${ }^{89}$ The foundational study is Peter L. Berger \& Thomas Luckmann, The Social Construction of Reality: A Treatise in the Sociology of Knowledge (1967) (social reality is a human construction, a product of social interaction: we negotiate meanings and values, and as we reach agreement on what constitutes reality, our social constructions, meaning our shared understandings and valorizations, become stable).

${ }^{90}$ Ann Swidler, Culture in Action: Symbols and Strategies, 51 Am. Sociological Rev. 273 (1986) (culture is a "toolkit" from which people select symbols, stories, rituals, and worldviews that they apply to particular situations, thus creating strategies of action); William H. Sewell, Jr., A Theory of Structure: Duality, Agency, and Transformation, 98 Am. J of Sociology 1 (1992) (social actors' actions are constrained by their shared cultural schemas and by the symbolic and material resources available to them, but at the same time, actions reproduce cultural schemas and resources; the upshot is that social actors organize their actions and their interpretation of those actions around established cultural schemas, which both modifies those schemas and establishes new shared meanings for actions).

${ }_{91}$ Warren O. Hagstrom, The Academic Community (1965) (academic training socializes people into the paradigms associated with particular disciplines); Magali S. Larson, The Rise of Professionalism (1977) (in modern societies, professional values are most effectively transmitted through training in professional schools).

92 Howard S. Becker, Blanche Geer, Everett C. Hughes, \& Anselm L. Strauss, The Boys in White: Student Culture in Medical School (1961) (based on direct observations and interviews of medical students throughout their training at the University of Kansas medical school).

${ }^{93}$ Howard S. Erlanger \& Douglas A. Klegon, Socialization Effects of Professional School: The Law School Experience and Student Orientations to Public Interest Concerns, 13 L. \& Soc. Rev., 11 (1978) (the biggest change law-school
} 
"the language of law" ${ }^{94}$ and "legal reasoning," 95 and to emphasize authority and downplay morality in judgements of human conflict that are reported in legal documents. For disciplines outside the professions, it is in graduate academic programs that students "imprint" on academic standards - i.e., where they first learn the theoretical principles guiding academic research, methodological techniques for conducting that research, and norms about research and teaching. ${ }^{96}$ And it is in graduate programs that students forge the social networks that reinforce those norms. ${ }^{97}$

Of course, students are not "cultural dopes," passive vessels into which educational institutions pour abstract ideas and normative schemas about how best to deploy them. ${ }^{98}$ Instead, students actively reconstruct the logics they learn in school, through their own actions and through their interactions with others in their school, and they often modify the logics they

students undergo is to "think like a lawyer," meaning to distinguish legal from non-legal issues, dispassionately see multiple sides of any problem, and reason logically and unemotionally); Elizabeth Mertz, Learning to "Think Like a Lawyer" (2007) (legal epistemology, meaning the way law is taught, pushes students to focus pragmatically on coldly logical connections between the cases they are discussing in class and prior cases and court decisions, on cases' procedural histories, and on the authority hierarchy among legal texts and legal decision makers. Legal epistemology, especially the Socratic method used in teaching doctrinal law, pushes students away from focusing on issues of morality and fairness. The Socratic method has a strong symbolic resonance or "fit" with the legal profession's underlying worldview).

${ }_{94}$ E.G. Gee \& Donald Jackson, Current Studies of Legal Education: Findings and Recommendations, 32 J. Legal Educ. 471 (1982) (summarizing several studies showing that practicing attorneys agreed that dexterity with the language of law is important and is developed during law school).

${ }^{95}$ Bryant G. Garth \& Joanne Martin, Law Schools and the Construction of Competence, 43 J. Legal Educ., 469 (1993) (in surveys, practicing attorneys agreed that legal reasoning, the skill most important for practice, is well taught in law schools).

${ }^{96}$ See, e.g., David Gottlieb, Processes of Socialization in American Graduate Schools, 40 Social Forces, 124 (1961) (interactions between graduate students and faculty shape students' attitudes and career preferences); Ann E. Austin, Preparing the Next Generation of Faculty: Graduate School as Socialization to the Academic Career, 73 J. of Higher Educ., 94 (2002) (socialization in graduate school occurs through interactions between faculty and graduate students, as well as among graduate students; through these interactions, graduate students construct new roles and develop new conceptions of academic careers and the faculty role in higher education); Toby E. Stuart \& Waverly W. Ding, When Do Scientists Become Engineers? The Social Structural Antecedents of Commercial Activity in the Academic Life Sciences, 112 Am. J. of Sociology, 97 (2006) (graduate training has such strong effects on academics because it occurs at the beginning of their professional development).

${ }^{97}$ Stuart \& Ding, supra n. 96.

${ }^{98}$ Harold Garfinkel, Studies in Ethnomethodology (1967) (an ironic reference to the notion he attributed to many sociological theories holding that people conform to social norms without thought or resistance; instead, Garfinkel proposed that people are highly attentive to situations and skilled at deciphering them). 
encounter in unexpected ways. ${ }^{99}$ Nonetheless, formal education legitimates particular ways of thinking, speaking, and acting, and de-legitimates others.

Applying sociological insights on academic training and institutional logics to law professors suggests that training for the JD or an advanced law degree inculcates into law students a doctrinal legal logic, while training for a graduate degree outside the law inculcates into graduate students a disciplinary logic. In terms of academic practice, this means that, compared to law professors with only law degrees, law professors with advanced degrees outside the law will be less attached to traditional law-school institutions, including doctrinal analysis of case law, the Socratic method for teaching law, and publishing doctrinal scholarship in student-edited law reviews. Yet because the vast majority of law-school faculty holding PhDs also hold JDs or the equivalent, because most of these faculty earned their law degrees before their PhDs, and because few of these faculty held faculty positions in other disciplines before joining a law school faculty, these professors are not likely to import "alien" cultures and practices of the arts and sciences into the legal academy in a wholesale fashion. Instead, PhDholding faculty are likely to promote an intellectual culture that is a hybrid of the traditional legal academy and the arts and sciences, by first selecting components of external disciplines and then adapting them to the legal academy. ${ }^{100}$ Moreover, as recent research of newly hired law-school professors has shown, half of those with JDs and PhDs had served as law clerks for

\footnotetext{
${ }^{99}$ Binder, supra $\mathrm{n} .13$ (showing that organizational members' responses to organizational logics vary with local cultures; specifically, professional commitments, personal interests, and interactions with coworkers determine how employees of professional service organizations interpret and apply institutional logics to the tasks at hand; moreover, people in such organizations often confront multiple opposing or cross-cutting logics, and they show great creativity in combining and reconciling logics); Berman, supra $\mathrm{n} .13$ (showing that new institutional logics can take hold in an organizational field either when "institutional entrepreneurs" promote it and overcome resistance by those who favor existing institutional logics, or, if there are no institutional entrepreneurs, when changes in external conditions create new problems for organizations and experiments with new logics yield practices that prove useful for solving those problems).

${ }^{100}$ Westney, supra n. 13 and Guthrie, supra n. 13 (showing that selection and adaptation occurs instead of wholesale adoption because (1) existing historical and cultural contexts shape how external standards and practices (e.g., the introduction of Western ideas about bureaucracy into Meiji-era Japan or American ideas about corporate structure and governance into China in the 1990s) are understood and evaluated, and (2) existing systems determine what resources are available for putting new (selected and adapted) systems into practice)).
} 
judges after earning their JDs, although the fraction of newly-hired law-school professors with only JDs who clerked was considerably higher (at 76\%). ${ }^{101}$

One reason why law-school faculty with PhDs and JDs will select and adapt elements of the logics underpinning external disciplines, rather than importing those logics wholesale, is the high status of the law vis-à-vis most other academic disciplines. ${ }^{102}$ Law has always been a highstatus discipline, and it currently has higher status than the vast majority of the arts, humanities, and social science disciplines (with the possible exception of economics), for several reasons. First, law is a very old discipline - indeed, one of the oldest. The roots of the legal academy can be traced back to the Middle Ages or earlier: the University of Bologna, the first Western university, was founded in 1088 as a law school, focused on the study of canon and civil law. ${ }^{103}$ Discipline age is related to discipline prestige, with older disciplines being viewed as more prestigious than younger ones, simply by virtue of their long history. Second, the high status of law within the academy is bound to the high prestige of the legal profession in society. As one of the three traditional professions (along with theology and medicine), law has always been a highly prestigious occupation. ${ }^{104}$ Law and medicine are highly prestigious occupations precisely because they are professions - occupations whose members claim exclusive authority over the work they do, based on their specialized expertise, and whose

\footnotetext{
${ }^{101}$ LoPucki, supra n. 3, 524, Table 8; McCrary, Milligan, \& Phillips, supra n. 3 (in the top 34 law schools, the rise of faculty with PhDs has not replaced traditional law-school hiring criteria, as the proportion of new faculty with Supreme Court clerkships and law-review memberships has remained steady).

${ }^{102}$ The ranking of academic disciplines has a long history: See Aristotle, Metaphysics, Book I, Part I and Book VI, Part I, http://classics.mit.edu/Aristotle/metaphysics.mb.txt, last viewed May 10, 2016) (he ranked "theoretical" subjects (theology, mathematics, and physics) above "practical" subjects (ethics and politics), and ranked these above "productive" subjects (fine arts, harmonics, optics, and mechanics). For a more recent view, see Immanuel Kant, The Conflict of the Faculties, 1798/1992, translated by Mary J. Gregor, 25-29 (he put law, medicine, and theology in a category of "higher" disciplines and all other disciplines (literary studies, the humanities, the social sciences, and the natural sciences) in a category of "lower" disciplines; but of course he argued that philosophy transcended and linked all disciplines).

${ }^{103}$ See http://www.unibo.it/en/university/who-we-are/our-history/university-from-12th-to-20th-century (last visited May 10,2016).

${ }^{104}$ See Robert A. Ferguson, Law and Letters in American Culture (1984); Samuel Haber, The Quest for Honor and Authority in the American Professions, 1750-1900 (1991); Lawrence M. Friedman, A History of American Law, $3^{\text {rd }}$ Ed. (2005) (from the earliest days, American lawyers have been highly educated and well remunerated, and, despite several populist movements that scorned elites, including professionals, lawyers have also generally been well respected).
} 
entry requirements (not just advanced degrees, but also passage of exams for professional practice) are extremely difficult to surmount. ${ }^{105}$ Law and medicine are more prestigious than most occupations that are based on social-science training, the disciplinary home that is most common among law professors with advanced degrees outside the law: the occupational prestige score for lawyers is 75 and the socio-economic index score is 92 , while for doctors, the prestige score is 86 and the socioeconomic index score is 97 ; in comparison, for psychologists, economists, and sociologists, the prestige scores are 69,63, and 61 respectively, and the socioeconomic index scores are 83,85 , and 80 respectively. ${ }^{106}$

The high status of the law vis-à-vis other academic disciplines pushes holders of PhDs and JDs to retain rather than reject the culture and material practices associated with the doctrinal legal logic. ${ }^{107}$ This suggests that while legal scholarship began to incorporate ideas and practices associated with external disciplines, and law schools began to hire more faculty with advanced degrees in external disciplines, those ideas and practices would be used to make doctrinal arguments and any faculty members who did not apply the doctrinal logic would be marginalized: this is just what has been found in several empirical studies of the culture and practices of law professors and law schools in the wake of interdisciplinary challenges. ${ }^{108}$

\footnotetext{
${ }^{105}$ Larson, supra $\mathrm{n} .91$ (professions claim expertise in a specialized body of knowledge and techniques that they apply in their work, which requires extensive training to master; professions are singularly authoritative and prestigious occupations); Freidson, supra n. 32 (the credential system, which encompasses higher education and occupational entry exams, is the source of professions' rights, powers, and prestige).

${ }^{106}$ The occupational prestige score is a measure of social standing, while the socioeconomic index combines information on occupational prestige with information on the education required for a particular occupation and its associated income; both are assessed through opinion surveys of nationally representative samples of Americans. The scores for occupational prestige and socioeconomic index given above are taken from Keiko Nakao \& Judith Treas, Updating Occupational Prestige and Socioeconomic Scores, 24 Sociological Methodology 1 (1994), Appendix D at 42-69.

${ }^{107}$ Joseph Ben-David \& Randall Collins, Social Factors in the Origins of a New Science: The Case of Psychology, 31 Am. Sociological Rev., 451 (1966) (individuals moving from one academic discipline to another are in positions of role conflict because they have to choose between the attitudes and behaviors valued by the old discipline and those valued by the new, but if they derive high status from the old discipline, they may choose to develop hybrid attitudes and behaviors instead of choosing between the two disciplines).

${ }^{108}$ See, e.g., Bruce A. Ackerman, The Marketplace of Ideas, 90 Yale L. J., 1131 (1981) (arguing that "What is going on is a shift from one kind of doctrinal analysis to another," p. 1131, and "the primary purpose of the modern law professor remains much as it was in the past: to provide disciplined methods for evaluating the flow of legal decisions and to train students in these methods so they will intelligently practice them in their professional lives," p. 1131); Bryant G. Garth \& Joyce Sterling, From Legal Realism to Law and Society: Reshaping Law for the Last
} 
With regard to sociology, for example, one scholar explained that law "was a kind of black hole in American sociology. ... It no doubt had to do with the fact that the lawyers managed to be such impressive people and that they sounded as if they knew everything that ought to be known about the field and that you better not trespass on that territory unless you happened to be a lawyer." 109 The superior status of the law is why challenges to doctrinal legal scholarship from external disciplines always resulted in settlements that preserved law professors' autonomy. That professors with both PhDs and JDs tend to get their JDs before their PhDs (by a margin of almost two to one, or $60 \%$ to $35 \%$ ) further ensures the preservation of this autonomy, because among such professors, the law's earlier inculcation tends to give legal doctrine primacy over other disciplines. ${ }^{110}$

Yet there is some evidence that in one respect, law-school practices and norms have become more similar to those of outside disciplines, specifically in terms of publications required to earn tenure. The number of articles a law professor must publish to earn tenure increased from one or two in the 1980 s to four or more today. ${ }^{111}$ But those articles have

Stages of the Social Activist State, 32 Law \& Soc. Rev. 409, 461 (1998) (demonstrating that in the 1960s and 1970s, law schools quickly gained control of "the center of gravity in the field of law and social science" and that law schools marginalized both social and natural scientists); Christopher Tomlins, Framing the Field of Law's Disciplinary Encounters: A Historical Narrative, 34 Law \& Soc. Rev. 911, 965 (2000) (the legal academy has successfully faced down challenges to its autonomy in the academy and its authority in society from other practitioners of social knowledge, including challenges that began in the 1960s from economics and sociology; instead of absorbing the values and methods of external social-science disciplines, the legal academy has seen "the successful appropriation of what it could use and its indifference to, and eventual discard of, what it could not"); Laura Kalman, Professing Law: Elite Law School Professors in the Twentieth Century, in Austin Sarat, Bryant Garth \& Robert A. Kagan, eds., Looking Back at Law's Century (2002) (arguing that in the face of incursions of social science from the 1960s and 1970s onward, "the law school embraced just enough reform to preserve law's autonomy," p. 354. "[A]cademic lawyers retained ownership of law [and] colonized sociolegal studies," p. 355. "For all the "law and' electives cluttering the law school curriculum, doctrinal scholarship ... remained the norm," p. 356. But in the 1980s and 1990s, there was more of a true meeting of the minds, "progress toward a disciplined interdisciplinarity in the law school" and "the gap between law professors and other academics was narrower, that between law professors and the profession wider than during the 1930s or 1980s.... [and as a result,] law professors seemed more a part of the university than they were part of their own profession," p. 369).

${ }^{109}$ Richard Schwartz, quoted in Garth \& Sterling, supra. n. 102, at 430.

${ }^{110}$ Stanley Fish, There's No Such Thing as Free Speech (and It's a Good Thing Too), 231-242 (1994) (arguing that academics' original disciplines have such strong holds on them that interdisciplinarity may actually be impossible one cannot escape one's discipline's cognitive schema; instead, one assimilates information from and about other disciplines into that pre-existing schema).

${ }^{111}$ Although there is a great deal of commentary about tenure standards at law schools, including how they have risen in the past three or four decades, there is no rigorous research documenting those standards. See e.g., Clyde 
generally remained focused on doctrinal analysis. ${ }^{112}$ Moreover, tenure rates in law schools remain higher than those in other disciplines, and law schools confer tenure earlier than other disciplines. $^{113}$

Distinguishing among faculty by cohort, based on year of highest degree, we found that the fraction of law-school faculty with JDs but no other advanced degrees decreased continuously since the 1970s, while the fraction with PhDs increased continuously. By the 2011-12 academic year, more than one in eight law-school professors had PhDs, while just under two-thirds had JDs but no other advanced degrees. Our data also showed that the fraction of law-school faculty with master's degrees decreased continuously since the 1970s. This suggests that law professors are engaged in a credentialing race, with more advanced (PhD versus master's) credentials becoming an increasingly important axis of competition for law professors: to compete for law-school positions, prospective law professors increasingly accumulate advanced degrees. ${ }^{114}$

W. Summers, American Labor Law Scholarship-Some Comments, 23 Comp. Lab. L. \& Pol'y J., 801, 803 (2001-2002) (stating that to earn tenure, law professors should publish one or more law review articles within five or six years); Devon W. Carbado \& Mitu Gulati, Tenure, 53 J. Legal Educ., 157, 160 (2003) (stating that to earn tenure, law professors must publish two to four articles within five years).

${ }^{112}$ Ackerman, supra n. 108.

${ }^{113}$ Between 1979 and 1989, 69.9\% of law professors eligible for tenure in American law schools were awarded tenure (Association of American Law Schools, Report of the AALS Special Committee on Tenure and the Tenuring Process, 42 J. Legal Educ., 477, 485 (1992)), and tenure standards are laxer in law schools than in outside disciplines (Richard A. Posner, Legal Scholarship Today, 115 Harv. L. Rev., 1314, 1323 (2001)). No more recent rigorous data on law school tenure rates are available, but blogs frequently report that tenure rates in law schools are very high compared to outside disciplines(e.g., http://leiterreports.typepad.com/blog/2004/06/why is it so ea.html; last viewed July 5, 2016). Data on tenure rates outside law schools are sparse, but one report of universities participating in the American Universities Data Exchange (Florida, Illinois, lowa, Maryland, Michigan, Northwestern, Penn State, Pittsburgh, Rutgers, and Wisconsin) showed that $53 \%$ of those who took tenure-track positions in 1997-98 academic had earned tenure seven years later (Penn State, Faculty Tenure-Flow Rates: 2009-10 Annual Report, Table 2 (2010) (www.opia.psu.edu/january-2010, last viewed July 5, 2016). One published paper reports that among assistant professors in the fields of science, technology, engineering, and mathematics who were hired between 1990 and 2002 at 14 research-intensive universities, 64.2\% were promoted to associate professor (Deborah Kaminski \& Cheryl Geisler, Survival Analysis of Faculty Retention in Science and Engineering by Gender, 335 Science, 864). It is important to note that in many, but certainly not all, of these universities, associate professors are tenured. Tenure rates tend to be lower in more prestigious universities; for example, among assistant professors hired at Stanford between 1974 and 1978, 32.3\% earned tenure; rates for those hired 1979 to 1983 and 1989 to 1993 were $50.5 \%$ and $41.2 \%$, respectively (http://news.stanford.edu/news/2002/february6/jrfaculty-a.html; last viewed July $5,2016)$.

${ }^{114}$ On academic degrees as job-market credentials, see Collins, supra n. 32. 
It is notable that almost nine out of ten faculty with PhDs also had JDs. We found that this was due in large part to two parallel trends: law-school faculty with JDs became increasingly likely to hold PhDs, and law-school faculty with PhDs became increasingly likely to hold JDs. This means that law-school faculty with PhDs but not JDs became increasingly rare, dropping from just over three percent of the faculty whose law-professor careers began before 1971 to just over one percent of the faculty whose law-professor careers began between 2001 and 2011. These trends also suggest that instead of adhering to the traditional doctrinal legal logic or adopting pure external disciplinary logics, law schools' cultures and material practices may continue to develop into hybrids that reflect interdisciplinary logics - those that combine most elements of the traditional doctrinal logic with selected and adapted elements of external disciplinary logics. Yet this conclusion may be premature, as research in social psychology and sociology has shown that organizational cultures, like many other aspects of organizational structures and activities, are slow to change, ${ }^{115}$ even in the face of turnover among organizational members. ${ }^{116}$ In the near future, as law schools experience waves of retirements from among the older cohorts of law professors, many of whom held JDs but no other advanced degrees $(11.46 \%$ of professors with JDs but no other advanced degrees were in the 1938-1970 cohort and $25.86 \%$ were in the $1971-1980$ cohort), the traditional doctrinal culture

\footnotetext{
${ }^{115}$ On inertia in organizational structures and everyday activities, see Michael T. Hannan \& John Freeman, Structural Inertia and Organizational Change, 49 Am. Sociological Rev. 149 (1984) (proposing eight constraints on organizational change: investment in plant, equipment, and specialized personnel; limits on the internal information received by decision-makers; vested interests; organizational history, which justifies past action and prevents consideration of alternatives; legal and economic barriers to entry and exit; constraints on the external information gathered by decision-makers; legitimacy considerations; and the problem of collective rationality and the general equilibrium). On inertia and the evolution of organizational cultures, see Luigi Luca Cavalli-Sforza and Marcus Feldman, Cultural Transmission and Evolution (1991); Edgar H. Schein, Organizational Culture and Leadership, $4^{\text {th }}$ Ed. (2010) (proposing that organizational cultures are most malleable early in organizations' histories and they become more inert as time passes, even in the face of evidence that the existing culture creates problems for organizational performance, because organizational members ignore evidence of problems in order to safeguard their privileges and their sense of self).

116 J. Richard Harrison \& Glenn R. Carroll, Keeping the Faith: A Model of Cultural Transmission in Formal Organizations, 36 Administrative Science Q., 552 (1991) (computer simulations show that even in the face of rapid turnover rates, socialization by peers and superiors can sustain an organization's culture, especially when recruitment takes into consideration fit between the existing organizational culture and the values and beliefs espoused by potential recruits).
} 
may persist because it is sedimented in law-school practices, such as the first-year curriculum's emphasis on doctrinal analysis of case law and widespread use of the Socratic method for teaching law. ${ }^{117}$ Moreover, despite criticism, these practices were instituted over 140 years ago at a highly prestigious law school, Harvard, and they are understood by many law professors and by current and prospective JD students, as well as students' prospective employers, as legitimate. ${ }^{118}$

Our analysis also shows that male law professors were far more likely than their female counterparts to hold PhDs, but they were also far more likely than their female counterparts to be employed by top-tier law schools when they did not hold PhDs or other advanced degrees. These findings are consistent with research finding that hiring universities do not give female professors equal credit for equal credentials, and may prefer men with inferior credentials to women with superior credentials. ${ }^{119}$ This gender gap in the stratification of faculty across the law-school prestige hierarchy indicates that even though some things have changed, general patterns of inequality have persisted. ${ }^{120}$ It also indicates that, even a half century after the

\footnotetext{
${ }^{117}$ Steven Friedland, How We Teach: A Survey of Teaching Techniques in American Law Schools, 20 Seattle U. L. Rev., 1 (1996) (reports on a survey of 358 law-school professors about their teaching methods; finds strong use of the Socratic method in first-year courses and less use in large upper-level courses and small seminar courses); William M. Sullivan et al., Educating Lawyers: Preparation for the Practice of Law (2007) (survey of legal education practices in the United States and Canada finds that the case method is common and that it succeeds in making students acquire legal thinking skills).

${ }^{118}$ See, e.g.,, Russell L. Weaver, Langdell's Legacy: Living with the Case Method, 36 Vill. L. Rev., 517 (1991) (describes the long history of the Socratic method and its use in American law schools, justifies its use, notes problems with it for some kinds of courses, and offers suggestions to ameliorate those problems); Phillip E. Areeda, The Socratic Method (SM) (Lecture at Puget Sound, 1/31/90), 109 Harv. L. Rev., 991 (1996) (posthumously published outline of a lecture explaining and defending the Socratic method, and offering advice for how to avoid the harms cited by the method's critics); Michael Vitiello, Professor Kingsfield: The Most Misunderstood Character in Literature, 33 Hofstra L. Rev., 955 (2005) (a spirited defense of the harsh version of the Socratic method used by Professor Kingsfield, a character in The Paper Chase, a film about first-year law-school students at Harvard Law School that was released in 1973).

${ }^{119}$ Sarsons, supra n. 9 (finding that female economists receive less credit than male economists for co-authored publications when being considered for promotion to tenure, especially for publications that include both a male and a female author; this finding is not explained by any first author preference, because in economics authors are listed alphabetically).

${ }^{120}$ See also Merritt \& Reskin, supra n. 2 (finding that female law professors were less likely than their male counterparts to be hired into the top 16 law schools); McCrary, Milligan, \& Phillips, supra $\mathrm{n} .3$ (finding that female law professors with PhDs were less likely than their male counterparts to hold positions in the top of the 34 law schools, and this likelihood was less for more-prestigious law schools).
} 
passage of Title IX of the Civil Rights Act, law-school recruiting practices have not completely leveled the playing field for women and men. To be sure, women have continued to be underrepresented among law professors - most acutely among the least credentialed professors at the most prestigious law schools-in large part because of "demographic inertia," meaning that many employment positions continue to be occupied by people who were hired before discriminatory hiring and promotion practices were curtailed, even decades after those changes were made. ${ }^{121}$ Although faculty retirements in the near future will present an opportunity to reduce gender inequality, especially at the most prestigious schools, where most male professors came from cohorts who earned their highest degrees prior to 1990 and more than $40 \%$ came from cohorts who earned their highest degrees prior to 1980 , it will be difficult to overcome demographic inertia if law schools continue to hire new female faculty at rate of less than half, as was the case for the most recent cohort we studied (2001-11). Finally, the gender gap among law professors reported here indicates that even though the training of legal academics has changed, patterns of inequality in achievement have persisted. The rise of interdisciplinarity has reinforced, not reduced, the gender gap in access to tenured and tenuretrack faculty positions at law schools. ${ }^{122}$

\section{B. Law Schools}

We found that PhD-trained faculty remain concentrated in the most prestigious law schools, although the influx of PhD-trained faculty has trickled down the ranks to many less

\footnotetext{
${ }^{121}$ See William E. Feinberg, At a Snail's Pace: Time to Equality in Simple Models of Affirmative Action Programs, 90 Am. J. of Sociology, 168-181 (1984) and Lowell L. Hargens \& J. Scott Long, Demographic Inertia and Women's Representation among Faculty in Higher Education, 73 J. of Higher Educ., 494-517 (2002) (increases in the hiring and retention of underrepresented groups reduces historical inequality only after a time lag that may be decades long).

122 Indeed, although the opening of faculty positions to women may have spurred competition and therefore additional credentialing in the form of JD-PhD training, it is also possible that the persistence of women's underrepresentation among law professors has impeded the rise of interdisciplinarity, which may be less beneficial to men. See Allison K. Shaw \& Daniel E. Stanton, Leaks in the Pipeline: Separating Demographic Inertia from Ongoing Gender Differences in Academia, Proc. R. Soc. B, 279, 3736-3741 (2012) (arguing that demographic inertia in academia may reinforce structural inertia, or resistance to organizational change, as described by Hannan \& Freeman, supra n. 115).
} 
prestigious schools. This suggests that PhD credentials have become an important axis of competition for law schools (as well as law professors), as schools increasingly hire candidates with more and more advanced degrees to compete for prestige via media rankings. The upshot is that the legal academy is engaged in a credentialing race, with more degrees (JDs plus PhDs versus JDs alone) and more advanced degrees (PhDs versus masters') serving as marks of distinction. ${ }^{123}$ This suggests that the rise of interdisciplinarity did not erode the traditional prestige hierarchy in the legal academy, but rather reinforced it.

In one sense, the concentration of PhD-toting faculty in the top ranks of the law-school prestige hierarchy is surprising, as the incursion of such faculty involved one interdisciplinary movement that occurred far from the top of the prestige hierarchy. The law-and-society movement was originally (in the early 1960s) based in four law schools (Berkeley, Wisconsin, Denver, and Northwestern) that received funding from the Russell Sage Foundation to establish centers for the study of law and society; these schools were well outside that era's most elite group of law schools (Yale, Harvard, Columbia, and Chicago). ${ }^{124}$ But upon reflection, the concentration of PhD-toting faculty in the top ranks of the law-school prestige hierarchy is not really surprising, as other interdisciplinary movements originated in the top law schools, most notably, law and economics, whose current formulation (1960s onward) is most closely associated with the University of Chicago ${ }^{125}$ and whose members constitute the largest fraction of law faculty with PhDs, at least at the most highly ranked law schools. ${ }^{126}$ Moreover, the rise of faculty with PhDs occurred around the same time that the USNWR rankings appeared: the first UNWR ranking appeared in 1987 and these rankings became annual starting in 1990, while the percentage of law professors with PhDs rose from $5 \%$ in $1988-89$ academic year ${ }^{127}$ to $13 \%$

\footnotetext{
${ }^{123}$ On academic degrees as job-market credentials and signals of quality, see Collins, supra n. 32.

${ }^{124}$ For details, see Tomlins, supra n. 103, at 953-959.

${ }^{125}$ For details, see Herbert Hovenkamp, Law and Economics in the United States: A Brief Historical Survey, 19 Cambridge J. of Econ., 331 (1995).

${ }^{126}$ Hersch \& Viscusi, supra n. 3 (finding that $26.14 \%$ of faculty in the top-ranked 26 law schools held PhDs in economics, compared with $48.01 \%$ in all other social-science disciplines combined and $25.85 \%$ in all disciplines outside social science combined).

${ }^{127}$ Borthwick \& Schau, supra n. 2.
} 
in the 2011-12 academic year. Although the UNWR rankings had dramatic effects on how revenue is allocated in law schools, how scholarships are awarded, how graduates find jobs, and how students are distributed between full- and part-time programs, the positions in these rankings, at least among the top schools, did not change greatly over time.

More evidence to support the conclusion that the rise of interdisciplinarity reinforced the traditional law-school prestige hierarchy comes from our finding that almost three-quarters of law professors with PhDs were trained in the 14 most prestigious law schools. This is slightly more than law professors in general, among whom 70\% come from the 14 most prestigious law schools. When we look inside the top 14 , we find even more evidence of interdisciplinarity reinforcing the law-school prestige hierarchy: almost half of the law professors with both JDs and PhDs who earned their law degrees in top-tier law schools did so at Yale or Harvard. This pattern has persisted even in the face of a huge increase in the number of PhD programs associated with law schools: in the $1991-2000$ cohort, 79\% of faculty were trained in the top 14 law schools (including $19 \%$ at Harvard and $24 \%$ at Yale), while in the $2001-2011$ cohort, $84 \%$ were (including $20 \%$ at Harvard and $27 \%$ at Yale).

\section{Conclusion}

The rise of interdisciplinarity in law schools, and its merits, have been debated in depth. Some scholars have argued that the rise of interdisciplinarity has strengthened the legal academy by broadening legal curricula and legal scholarship beyond traditional disciplinary law, while others aver that the rise of interdisciplinarity has reduced the autonomy of law in the university by introducing "alien" ideologies and practices. Despite this debate, there is little recent, reliable, and comprehensive evidence concerning where and when interdisciplinarity has entered the legal academy. Recent research has found that interdisciplinarity, in the form of faculty with PhD training outside the law, has gained a significant foothold in law schools, but this research is limited to the most prestigious law schools. Expanding on earlier research, we found that the rise of law-school faculty with PhDs was widespread, rather than limited to the 
most prestigious schools, and that the diffusion of PhD-trained faculty down the prestige hierarchy increased over time.

Furthermore, our results showed something that earlier research, and the broader debate about interdisciplinarity in law schools, has overlooked. Although law schools saw a constant influx of faculty with PhDs into tenure-track and tenured positions, the vast majority of those faculty also held JDs. We doubt, therefore, that PhD-trained faculty have imported totally alien values and practices from the arts and sciences into law schools and reduced their autonomy. Instead, we argue that the influx of PhD-trained faculty has more likely promoted an intellectual culture and academic practices that are hybrids of the traditional legal academy and the arts and sciences, adapting only selected external elements, rather than adopting them wholesale; such hybridization has yielded more of (almost) the same culture and practices.

The influx of PhD-holding faculty reinforced, rather than undermined, traditional lawschool hierarchies, in two ways. First, this influx was most pronounced at the top ranks of law schools, and most faculty with PhDs and JDs were trained in the top-ranked law schools notably, half in Yale and Harvard. The diffusion of PhD-trained faculty down the prestige hierarchy over time suggests that $\mathrm{PhD}$ credentials have become an important axis of competition for law schools (as well as law professors), as schools increasingly hire candidates with more and more advanced degrees to compete for prestige via media rankings. Second, even though the training of legal academics has changed, patterns of inequality in achievement between men and women have persisted. The rise of interdisciplinarity has not reduced the gender gap in access to tenured and tenure-track faculty positions at law schools, especially in the most prestigious schools.

We anticipate that the fraction of tenured and tenure-track law-school faculty with PhDs will continue to rise, and that the vast majority will continue to hold JDs. We also anticipate that the impact of interdisciplinarity on law schools, both their practices and the diversity of their faculty, will be limited by hybridization and institutional inertia, even as law 
schools experience waves of retirements from among the older cohorts of law professors in the near future. 